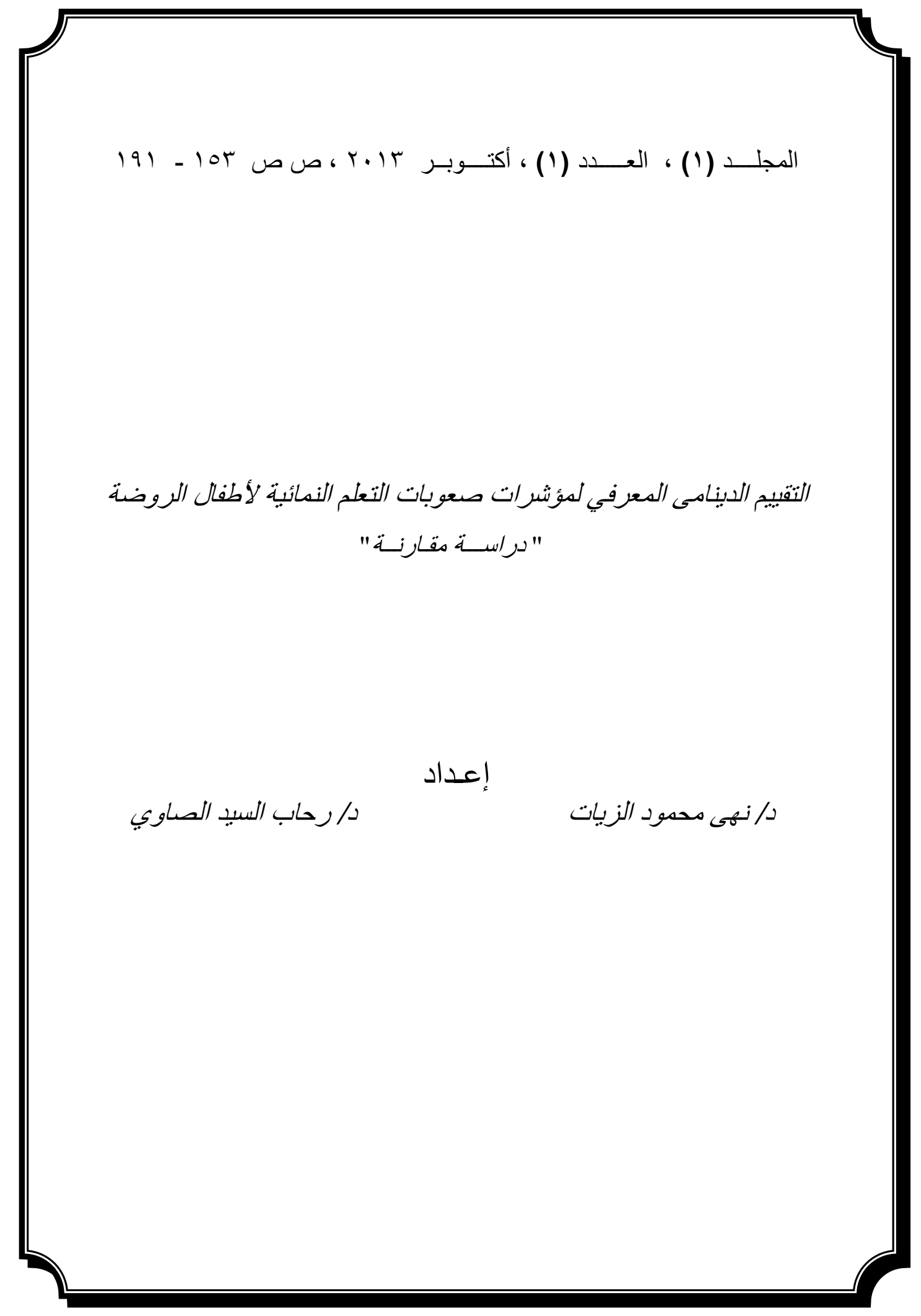


التقبيم الدينامى المعرفي لمؤشرات صعوبات التعلم النمائية لأطفال الروضة

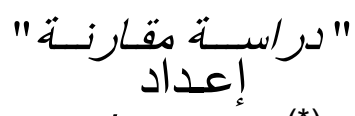

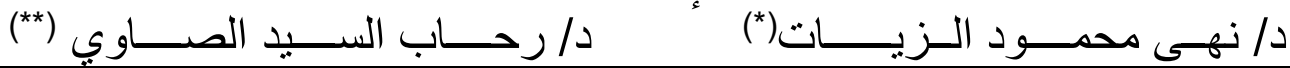

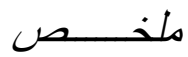

تهدف الدراسـة إلى التحقق من فاعلية التقييم الدينامي المعرفي في تقييم مؤشرات أداء

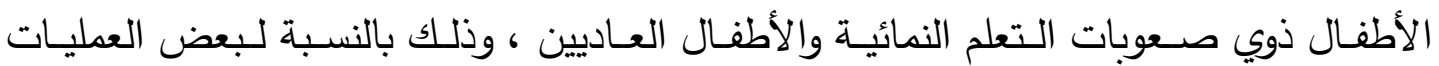
المعرفية المتمثلة في عمليات التخطيط والانتباه وعملية المعالجة المتزامنة والمعالجة المتتابعـة، وتكونــت عينـة الدراسـة مـن ( •0) طفـلاً مقسـمين الـى مجمـوعتين (مجموعــة الأطفــال ذوي

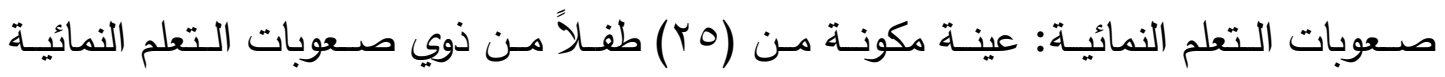
الملتحقين بالمستوى الثاني في مرحلـة رياض الأطفال من مدرسـة النيل بالعمرانية) و (مجموعـة الأطفال العاديين: عينة مكونة من (Y0) طفلاً من الأطفال العاديين الملتحقين بالمستوى الثاني في مرحلة رياض الأطفال من مدرسـة النيل بالعمرانية)، واستخدمت الدراسـة مقياس المصفوفات

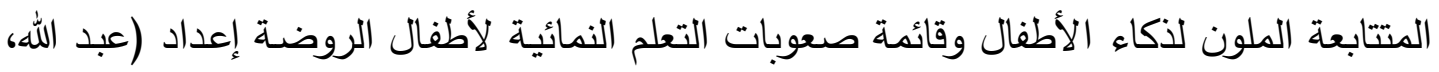

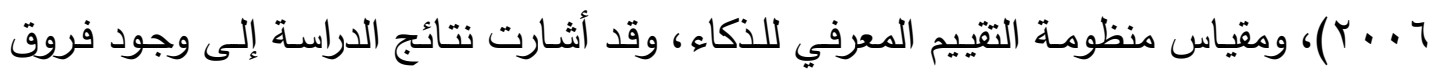

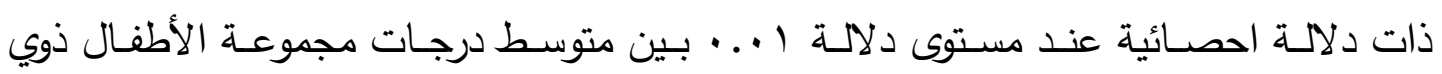
صعوبات التعلم النمائية في كل من التقييم الدينامي والتقييم التقليدي بالنسبة لبعض العمليات المعرفية (عمليات التخطيط والانتباه وعمليـة المعالجة المتزامنـة والمعالجة المتتابعة) وذلك في لمي اتجاه التقييم الدينامي، كما أثارت النتائج إلى وجود فروق ذات دلالة احصائية دالة عند مستوى ا +. · بـين متوسـط درجـات التقيـيم الدينامى المعرفي للأطفـال ذوي صـعوبات التعلم النمائيـة ومتوسط درجات التقييم التقليدي للأطفال العاديين وذلك على مقياس التقييم الدينامى للعمليات المعرفية (عمليات التخطيط والانتباه وعمليـة المعالجـة المتزامنـة والمعالجة المتتابعـة) في اتجاه درجات التقييم الدينامي للأطفال ذوي صعوبات التعلم. 
يحتل التقييم مكانة كبيرة في المنظومة التعليمية بكافة أبعادها وجوانبها على مر الأزمنة والعصور نظراً لأهميته في تحديد مقدار ما يتحقق من الأهداف المنشودة والتي يتوقع منها أن تتعكس إيجابياً على الطفل والعملية التربويـة على حد سواء، فضـلا عن أنه يعتبر عنصراً مهما وأساسياً لتحديد نقاط القوة والضـفف بمختلف أنواعها وتعدد مستوياتها، ومن ثم وضـع البرامج التنموية والإثرائية والتربوية الملائمة لكل طفل، فالتقييم يثري صانعي القرار بمعلومات من شأنها الارتقـاء بمستوى الخدمات، وتزداد هذه الأهميـة إذا ارتبطت بالأطفـال ذوي صـعوبات التعلم وتقيمهم لمـا نلمسـه في احتياجهم للتفهم والتقبـل لإمكانـاتهم وقدراتهم مقابـل الصـوبات التـي يواجهونها.

كمـا أن طـرق القيـاس التقليديـة بكافـه أنماطها وأنواعها أضـحت لا تجيــ من العلم سـى التركيز على تحديـد المسـتوى الحسالي للطفل نسـبة لأقرانـه، ويـتم التشـخيص فيهـا مـن خـلال الاختبارات التي تقدم لـه، وبناء على ما يظهره ذلك الطفل من استجابات صحيحة تكون درجته ويحدد مستواه، أي أنها تهتم بالمخرجات التي تظهر من خلال أدائه، دون أن تأخذ بالاعتبار البناء المعرفي والعمليات المعرفية التي يقوم بها ذلك الطفل للوصول لمثل هذه النتيجة. ويفسر بعض مستخدمي الاختبارات درجاتها على أنها قياسات ثابتة أو غير قابلة للنمو،

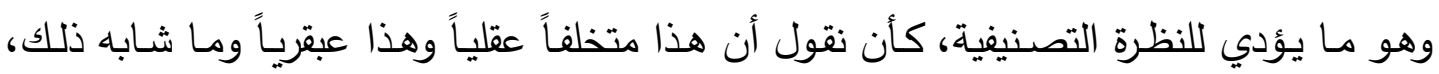

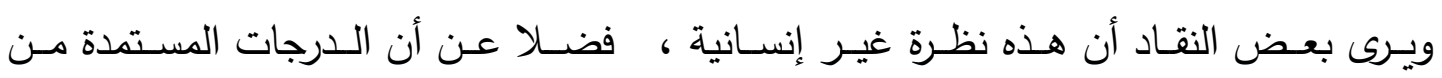
الاختبارات التقليدية تزودنا بقاعدة من البيانات تفيد في تصنيف الأطفال تصنيفًا اعتباريا. وهذا يعني أن هذه الدرجات ليسـت قياسـات ثابتـة ولكنها قيم تقديريـة لسمات إنسـانية، وبالتالي فهي تحتوي على أخطاء، غير أن هذه الاختبارات تستخدم عادة بطريقـة روتينيـة لا تتسم بالمرونـة الكافية التي تأخذ مختلف المتغيرات المؤثرة بعين الاعتبار (علام، . . . ؟) .

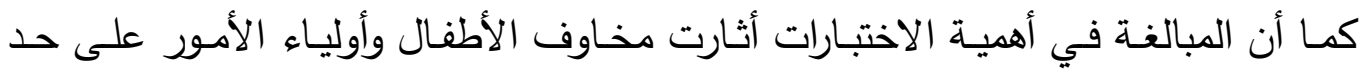
سـواء، وزيـادة مخـاوف الأطفـال مـن الاختبـارات يـؤدي إلى انخفـاض أداء الكثيـر مـنهم أثتـاء الاختبارات وذلك نتيجة للقلق والإرهاق البدني والذهني، كما أن هذه النتائج المبنية على مجموع الدرجات التي حصل عليها الطفل في الاختبار نتيجة ما بذله دن جهد في الحفظ وما أتقنه دن أسـاليب للغش وليس في ضـوء مـا لديـه من استعدادات وقدرات أو مواهب ممـا أدى إلى عدم تحقق أهداف القياس (كراجة، لو99 I ). 
ونظرا لما يعترض الاختبارات التقليدية من مشكلات حاولت منظومة التقييم المعرفي التي

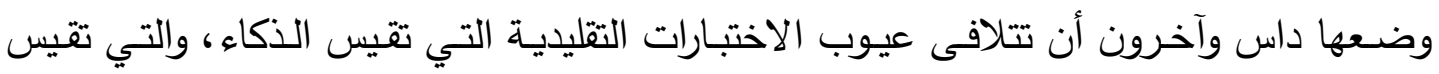

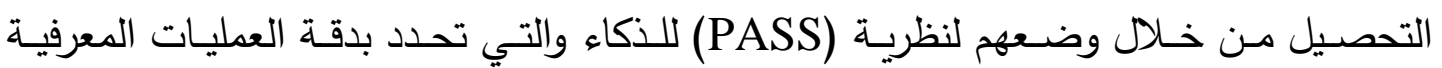
الأربعة التي تحدث داخل المخ والمسئولة عن معالجة المدخلات، قد تم تقسيم منظومة التقييم

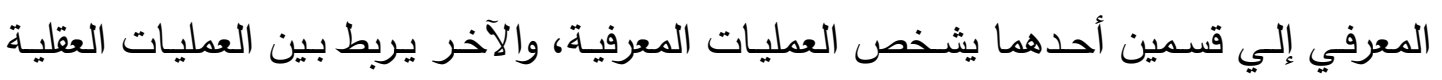

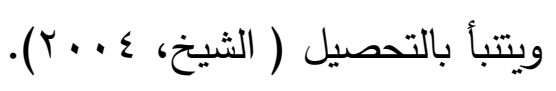

ويوفر التقييم الدينامي نوعاً من التدخل التعليمي والذي يسمى وساطة، ويتم تعديلها باستمرار

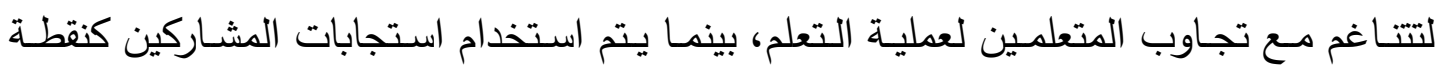

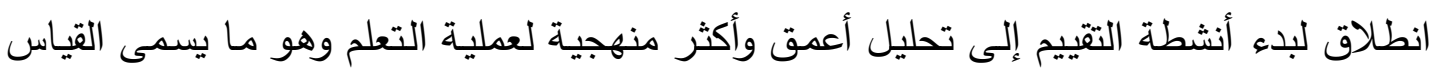
بالتدخل (Poehner \& Lantolf, 2005) وقد جاءت أهمية استخدام التعلم الوساطي للاهتمام بهذه الفئة من خلال التعرف على نقاط

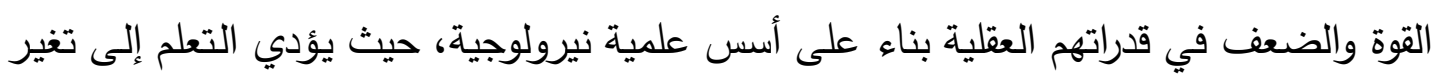

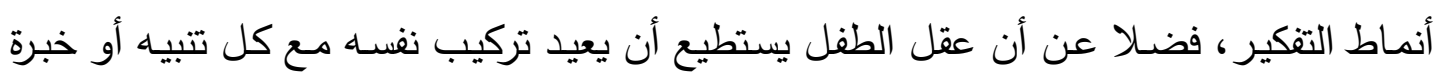

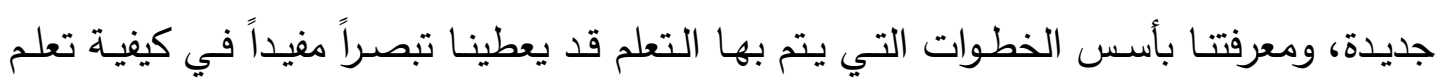
الأطفال ذوي صعوبات التعلم. وهكذا يتضـح مما سبق أن التقييم الدينامي، يعمل على تشخيص إمكانيات الطفل بشكل

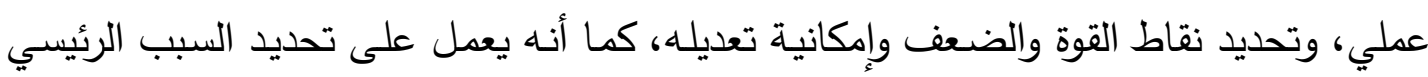

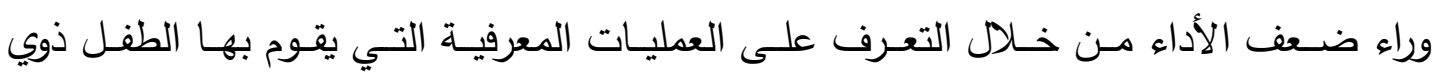

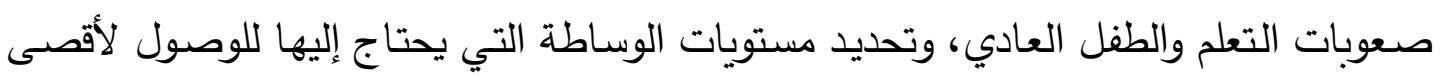

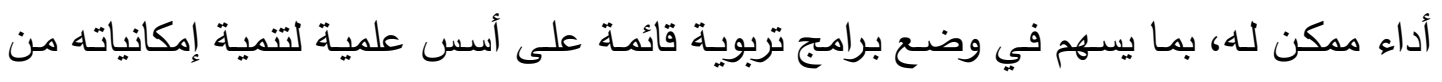

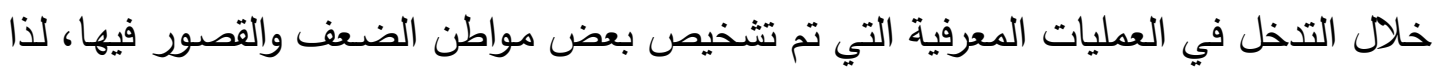
فإن كل ما نحتاج إليه التعرف على الفرق بين التقييم الدينامي والتقليدي في تتييم أداء الأطفال ذوي صعوبات التعلم وتحديد كناءتهم. 
يبـدو أنــا جميعـاً نعـيش نظـام التقيـيم التقليـدي الـذي يركـز على تسـجيل مجمـوع عـدد الاستجابات الصحيحة على الاختبارات، دون الوضـع في الاعتبار العمليات المعرفية التي قام

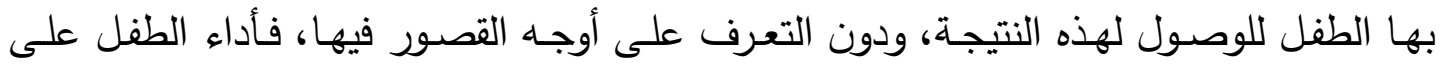
الاختبارات التقليدية لا يزود المتخصصين بالطريقة المفضلة لتعليمه. وفى ضوء هذه الانتقادات وفى ضوء ما توصلت لـه العديد من الدراسات في مجال التقييم الدينامي مثل دراسة الشيخ ( ؟ . . Y) والتي أوصت بضرورة دراسـة أثر استخدام التقييم الدينامي Swanson\& على عينـات أخرى غير المعاقين عقليًا، وأظهرت دراسـة سوانسـون وليسير Lussier الدينامي، وقد أظهرت نتائج تحليـل تلك الدراسـات وجود تفـاوت كبير في حجم الأثر تبعًا للمجموعة، حيث أظهرت أن الأطفال الأصغر سنا يحققون أعلى حجم تأثير من الأطفال الأكبر

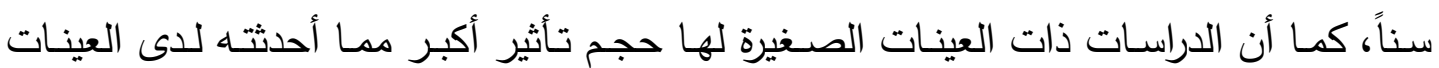
الكبيرة.

وكل هذا يؤكد على احتياج الطفل إلى بيئة تقييم ديناميـة لا تتوقف عند معرفة المستوى الحالي فحسب، بـل تتقدم بشكل انتقائي يتوقف على مستوى أداء كل طفل، بحيث لا تكون إجابة الطفل عن السؤال هي نهاية المطاف فيما يتعلق بهذه المشكلة، بل تصبح بداية نوع من التفاعل مـع الطفل بمـا يسـاعد على فهم أوجـه التميز والقصـور في إجابته، وعلى أسـاس ذلك يحدد القائم بالاختبار مستوى السؤال ومدى صـعوبته لكل طفل على حدة وفقًا لأدائه الفردي

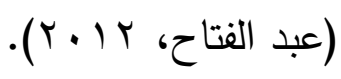

ومـن ثم يتضـح ممـا سبق أنـهـ تم التوصـل إلى قناعـة مؤداهـا أن أسـرع السبل إلى تغييـر وتطوير العملية التعليمية هو السـي إلى تغيير وتطوير نظام التقييم التقليدي واستخدام التقييم الدينامي كأحد الاتجاهات الحديثة، وذلك من أجل التعرف على البناء المعرفي للأطفال ذوي صعوبات التعلم والكشف عن مواطن القوة والضعف لديهج، وكذلك الكثف عن الاستراتيجيات التي تتتاسب مع إمكانياتهم بما يسهم في التخطيط الفارقي لعمليات التدخل. لذا يسعى البحث الحالي إلى تحديد الفرق بين التقييم الدينامي المعرفي والتثييم التقليدي لبعض العمليات المعرفية والتي تتمثل في عمليات التخطيط والانتباه وعمليات المعالجة المتزامنـة والمتتابعة (التاني والتتابع) في تقييم أداء الأطفال ذوي صسوبات التعلم والعاديين على حد سواء 
وتحديد كفاءتهم، والتعرف على الوظائف المعرفية لديهم من خلال التعرف على كفاءة العمليات المعرفية وعلاقتها ببعضها البعض ويتم ذلك من خلال الإجابة على السؤالين التاليين:

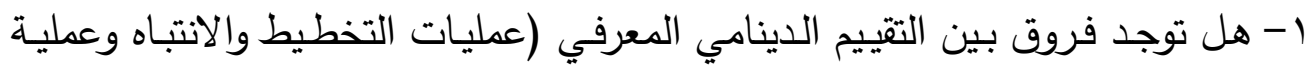

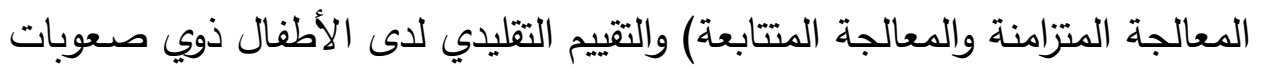
التعلم النمائية وذلك على مقياس منظومة التقييم المعرفي؟

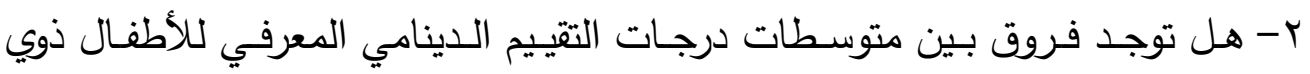

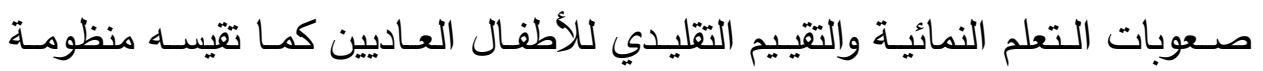

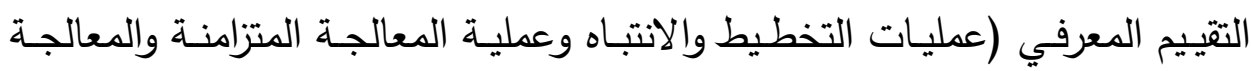

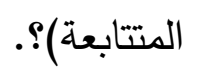

$$
\text { أهـداف الدراسة }
$$

1- الكثف عن الفروق بين التقييم الدينامي المعرفي (عمليات التخطيط والانتباه وعملية

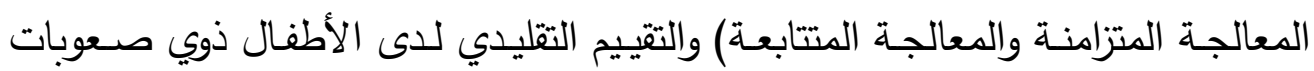

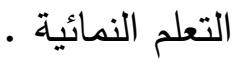
r- الكشف عن الفروق بين متوسطات درجات التقييم الدينامي المعرفي للأطفال ذوي

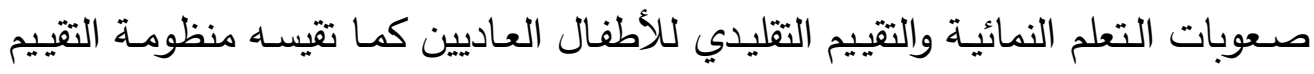
المعرفي (عمليات التخطيط والانتباه وعملية المعالجة المتزامنة والمعالجة المتتابعة).

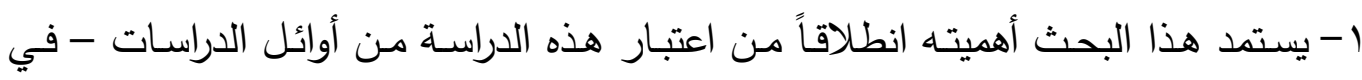

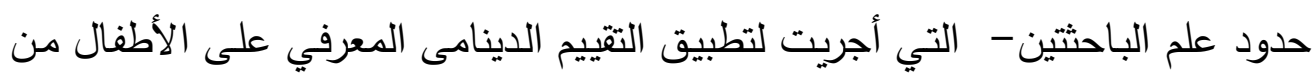
ذوي صعوبات التعلم النمائية. r- تشخيص جوانب القوة والضـف لدى الأطفال ذوي صعوبات التعلم والأطفال العاديين على حد سواء في البناء المعرفي بناء على أسس واقعية وموضوعية.

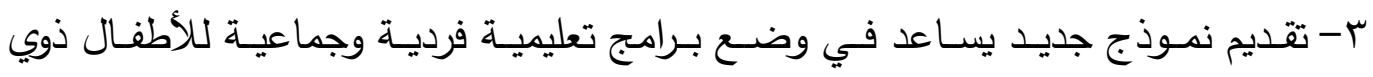

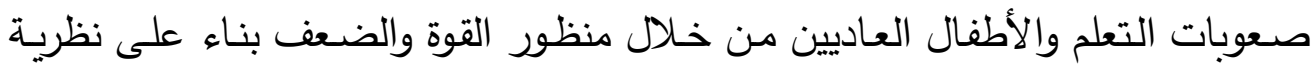
كتصور حديث للذكاء الإنساني. (PASS) 


$$
\text { مصطلحسـات الـدراســة }
$$

Cognitive Dynamic Assessment

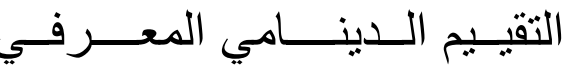
هو التيّيم الذي يسعى لقياس إمكانية الطفل للاستفادة من التعلم، أي الواسع المعرفي Learning Propensity خلال تفاعله مع البيئة، فالبيئة الغنية بالمشيرات المتجددة المتتوعة تتشط الـخ وتحفز العمليات

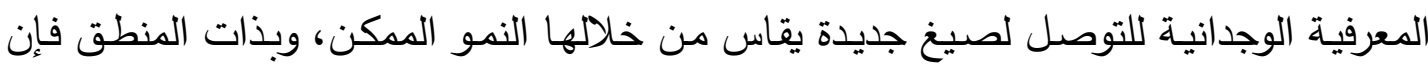
البيئة الرتيبة المحرومة من تلك المثيرات تعرض المخ للتيبس المعرفي الوجداني فتزداد الهوة بين

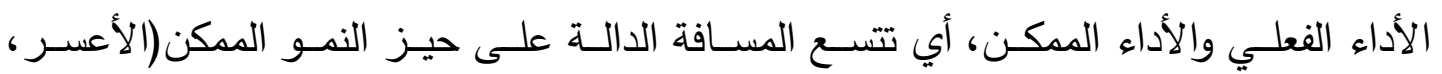

$$
\text { . ( ( . . ) }
$$

ويتضمن التقييم المعرفي عدد من العمليات المعرفية على النحو التالي:

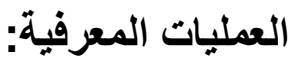

هي مجموعـة من القدرات المعقدة التي تميز الإنسـان عن الكائنات الأخرى، والتتي

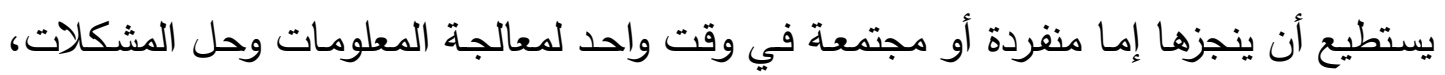

$$
\text { وتتحدد في: لبنطع ني }
$$

• التخطيط: هو عملية عقلية يحدد فيها الطفل وينتقي ويستخدم الحلول المتاحة للمشكلة، وتشتمل على حل المشكلة، وتشكيل التنكير ، وضبط الاندفاع، واسترجاع المعرفة، كما

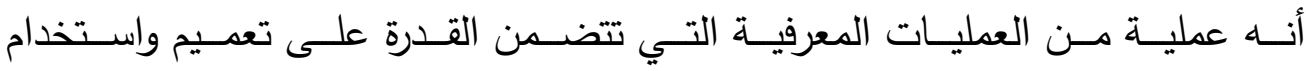

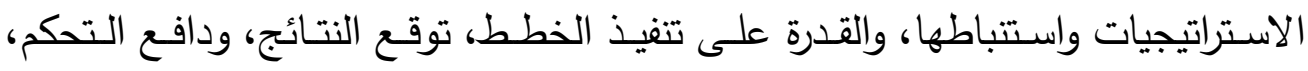

$$
\text { والتوجياه والتحكم الذاتي. }
$$

• الانتباه: هو عملية عقلية ينتقي الطفل فيها بعض المثيرات ويتجاهل المثيرات الأخرى،

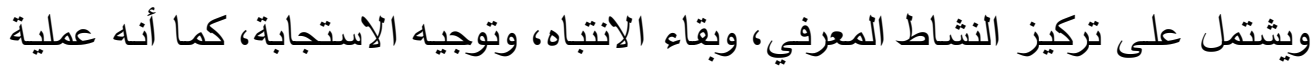

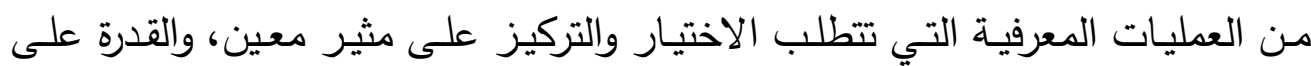
التركيز المباشر على التفاصيل الجوهرية والمعلومات المهمة ومقاومة التشتت الفكري.

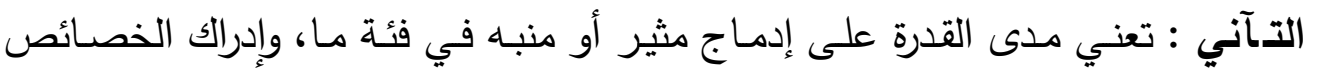

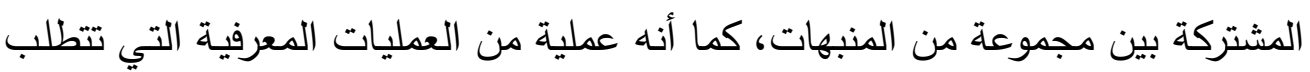

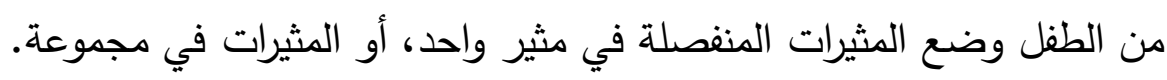


" التتابع: وفقًا للوريا تعني قدرة الطفل على أن يدمج أو يضع المثير داخل سلسلة مرتبة،

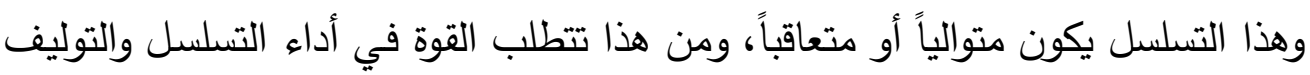

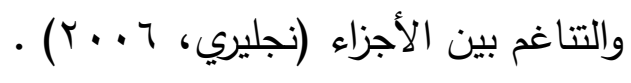

وتحدد إجرائيًا: بالدرجـة التي يحصل عليها طفل الروضــة على مقيـاس منظومـة التقييم

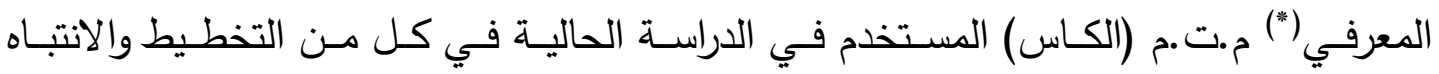
والمعالجة المتآنية والمعالجة المتتابعة والدرجة الكلية.

\section{Learning Disabilities}

صعـــــــــات التعلـــــ

صعوبات التعلم النمائية هي نقص في المهارات التي يختارها الطفل، والتي تتعلق بالوظائف

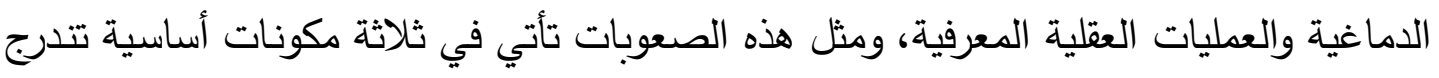

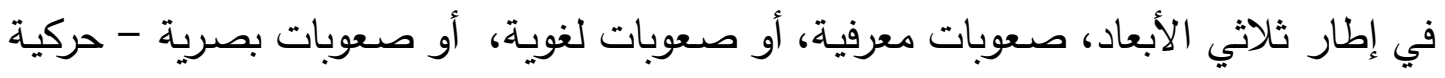

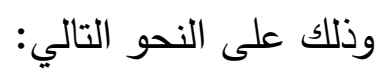

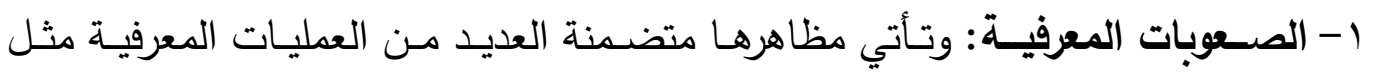
(صعوبات الانتباه، والإدرالك، والذاكرة. حيث أنها هي التي تؤثر على التمييز ، وتثكيل

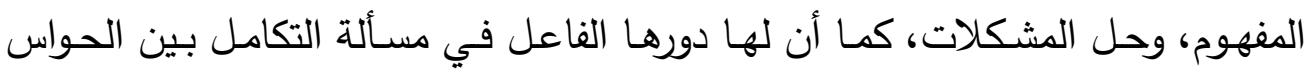

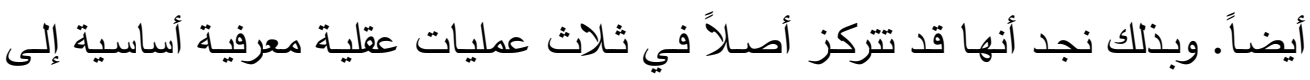
جانب بعض الأمور الأخرى التي تتعلق بها. r- الصعوبات اللغوية : وتتمثل مظاهرها في ( اللغة الثفوية، والتفكير السمعي، والإستقبال

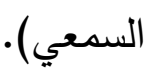
r- الصعوبات البصرية - الحركية: وتتمثل مظاهرها في (أداء مهارات حركية كبيرة تعكس

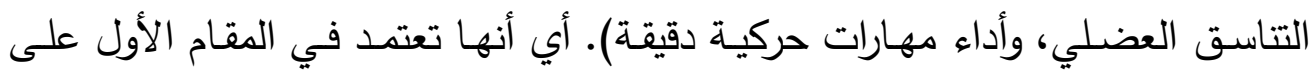

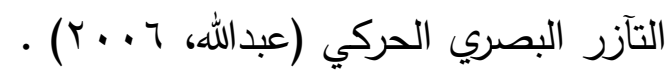
إطار نظري ودر/سات سابقة تقوم الباحثتان بإلقاء الضوه على على محورين أساسيين هما، التقييم الدينامي المعرفي، من حيث التعريف، والهدف منه، وخبرة التعلم الوسيط، والسبب وراء عزوف الباحثين عن التقييم 
الدينامي، ومراحل التشخيص الدينامي، والفرق بين التقييم التقليدي والتقييم الدينامي المعرفي، أم

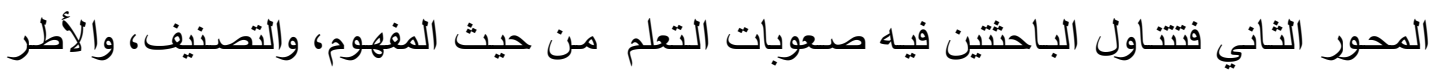
التفسيرية لصعوبات التعلم، وبيان ذلك فيما يلي: أولاً: التقييم الدينامي المعرفي

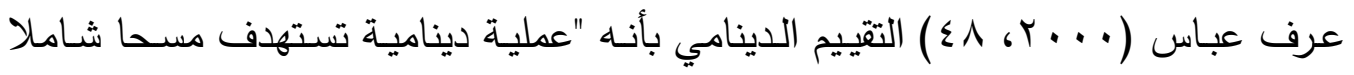

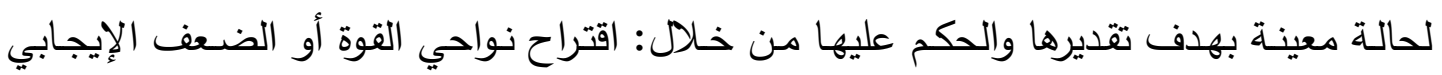
منها او السلبي، وتحديد الحكم الذاتي أو القرار الثخصي، والتتبؤ أو التوقع الستقبلي للحالة

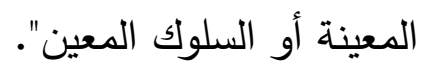

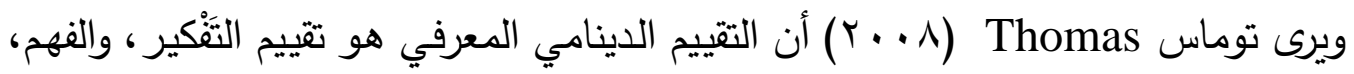
والتَعلم، وحل المشكلات، ويأخذ في الحسبان كل من النمو الفردي للطفلِ والمستوى الأعلى أي لهي

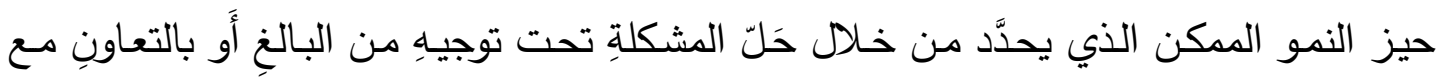

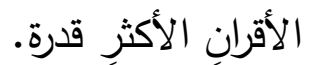

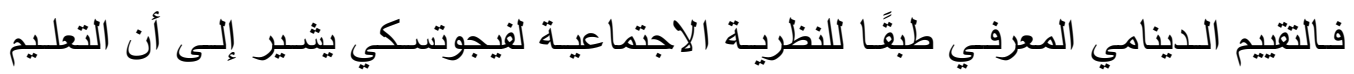

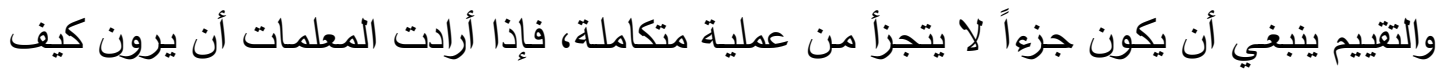
يتقدم أطفالهن حقا في تحصيلهم، فلا ينبغي أن يركز تقييمهن على أداء الأطفال في اختبار التحصيل النهائي في حد ذاته، بل ينبغي أن يكون التركيز الحقيقي على ما يستطيع الأطفال

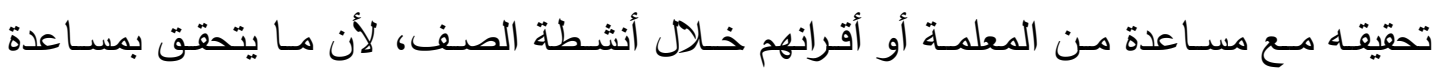
الآخرين يبين التقدم أو النمو المحتمل للتحقيق من دون أي مساعدة، فإذا استطاع الأطفال

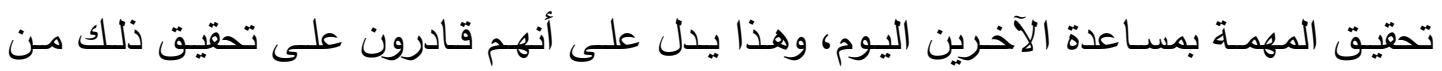

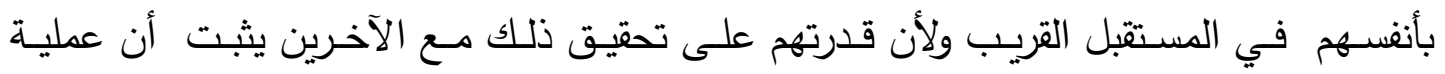
الاستيعاب قد بدأت بالفعل (Lantolf \& Thorne, 2006, 328).

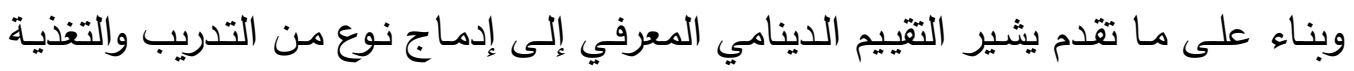

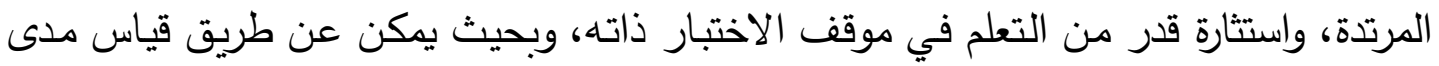

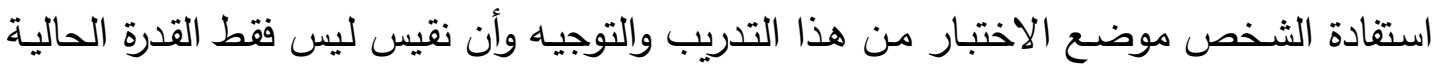

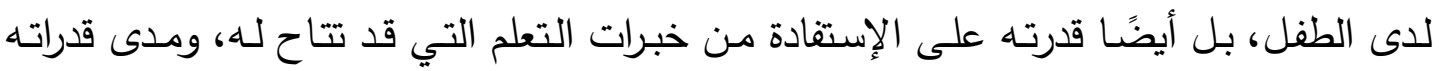

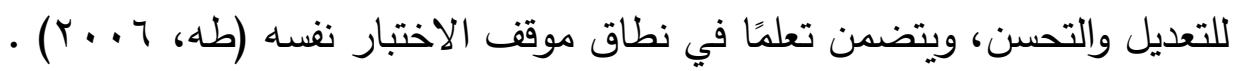




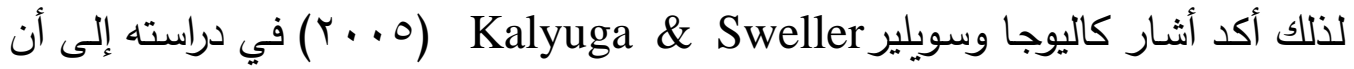

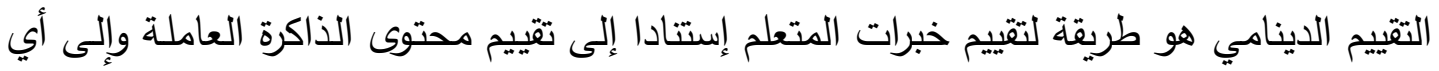

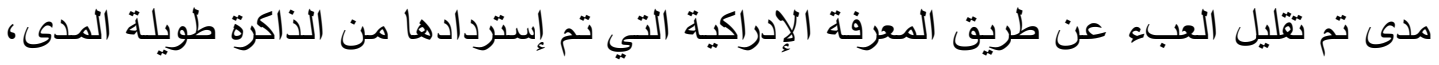
ويتم تصميم التعليمات بشكل ديناميكي لتغيير مستويات خبرة المتعلم باستخدام الإختبارات

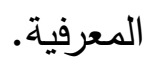

لذا جاءت الاتجاهات الحديثة لتغير النظرة إلى التقييم بصورته التقليدية، والتي تؤكد على

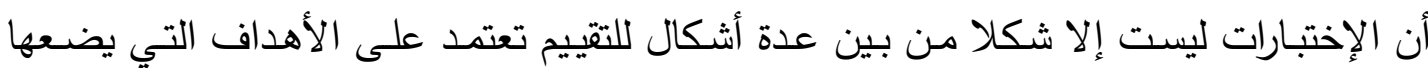

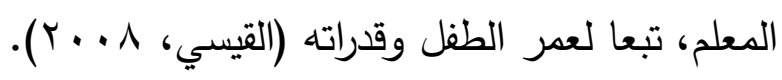

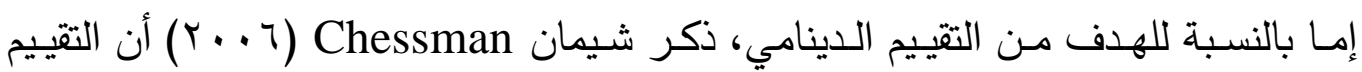
الدينامي هو الوحيد الذي يحدث على مدى فترة من الزمن ولا يقتصر على حدث واحد حيث

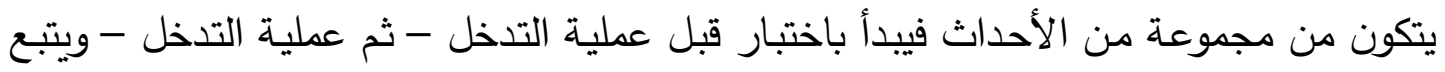
ذلك اختبار بعدي، في التتييم الدينامي يعرض الموقف على على الطفل أو المفحوص بطريقة تسهل

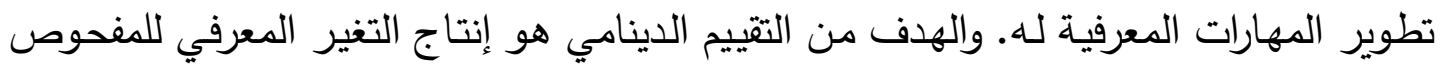
على المدى الطويل.

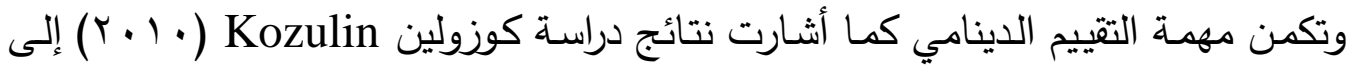

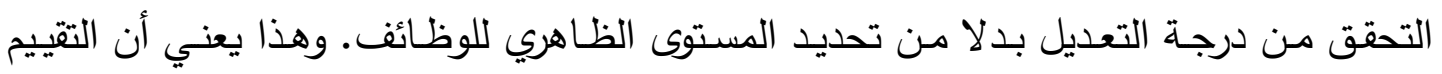

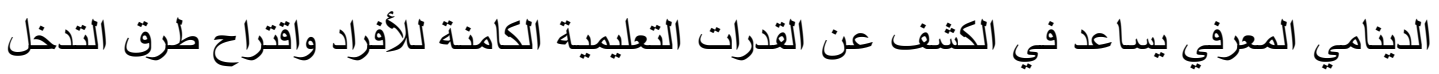

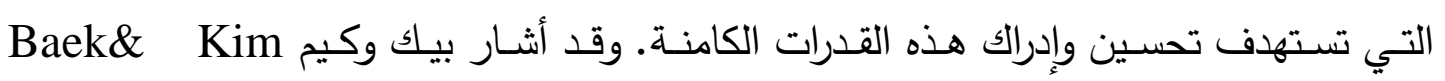

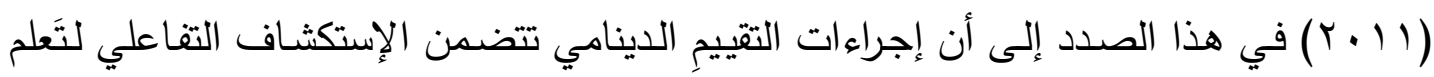

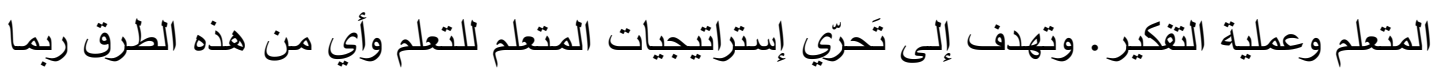

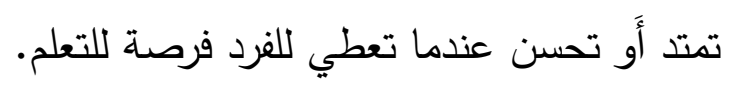

فالتقييم الدينامي لديـه امكانيـة إظهار معلومات هامـة وكامنـة عن استراتيجيات الطفل

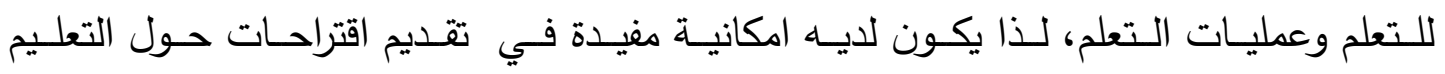
.( Baek\& Kim, 2011) كما أن هناك ثلاثة أبعاد أساسية يتميز بها التقييم الدينامي عن غيره من التقييمات يمكن

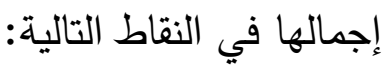
• التركيز : يمكن تقييم الطرق الكامنة وقياس إمكانية التغيير • 
" التفاعل: تغيير طبيعة التفاعلِ بين الفاحصِ والموضوع، لذا فالفاحص يتعامل كوسيط ليسكل عملية التعلم.

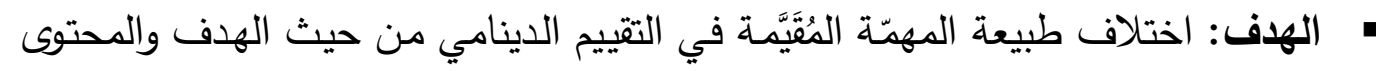

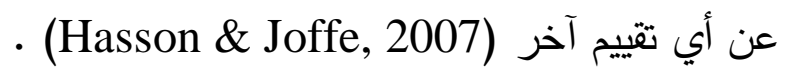

خبرة التعلم الوسيط

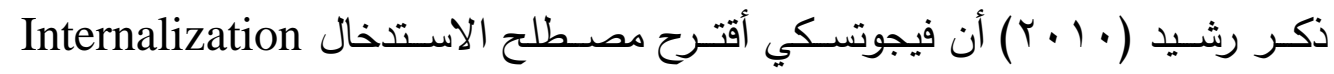
لوصف اعتماد الطفل على وسائل تتظيمية مستخدمة من قبل الآخرين، فالمجتمع هو صانع

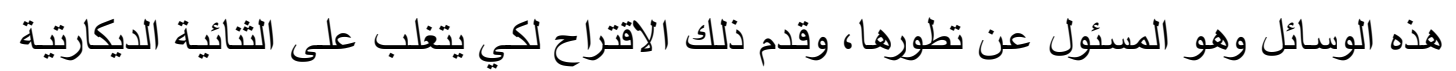

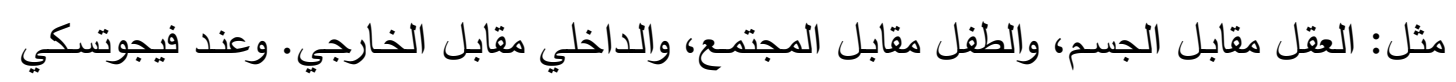
فإن الاستدخال هو مرحلة نمو تتوسط بين النشاط الخارجي والنشاط الداخلي. وبذلك يؤكد فيجوتسكي على أن التعلم يمكنه أن يتحول إلى نمو، وهذا يعني أن التعلم

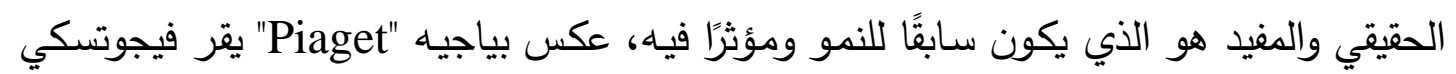
بأن التعلم مرتبط بمستوى نمو الطفل باعتباره معطى لا يناقش، ولكن في النمو يوجد مستويان

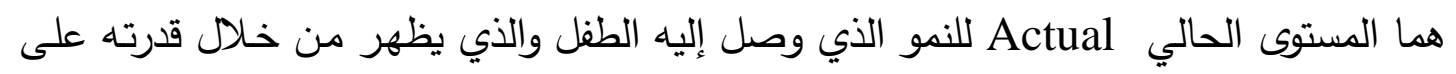

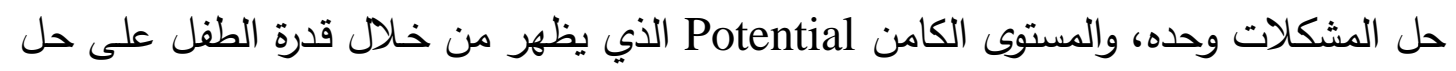

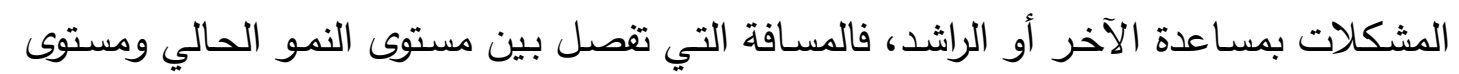

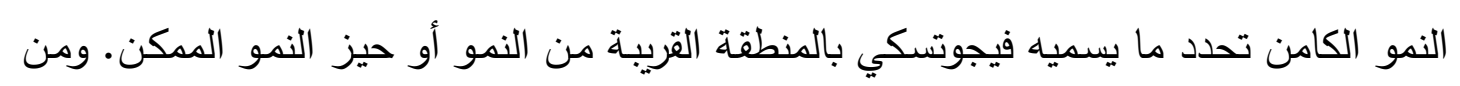

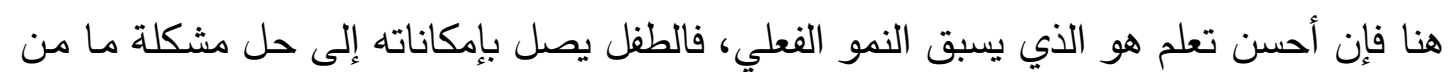

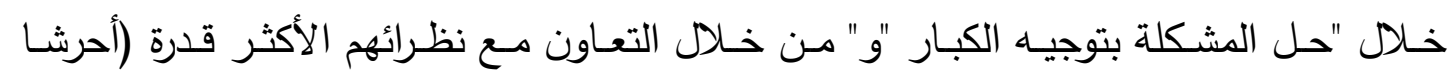

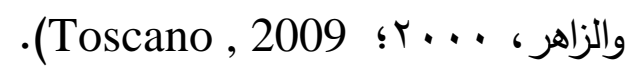

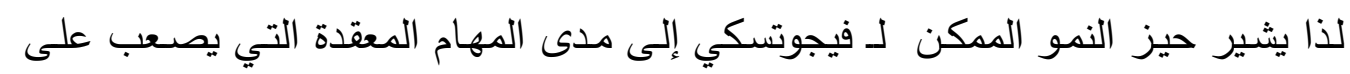

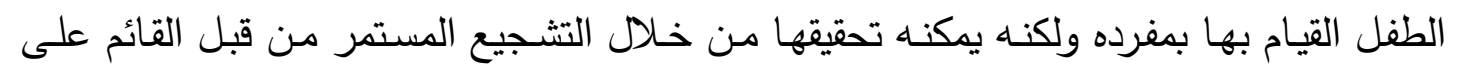

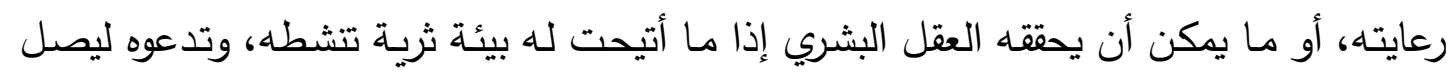

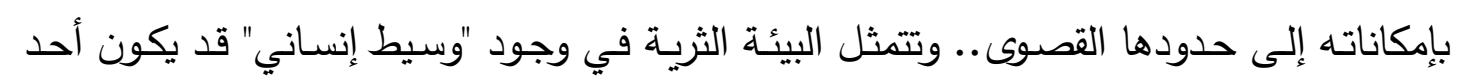

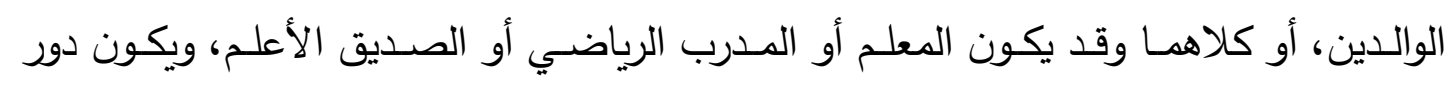


الوسيط تتشيط التفاعل بين الطفل وبيئته، من خـلال تنشيطه للعمليات العقلية الوجدانية بمـا

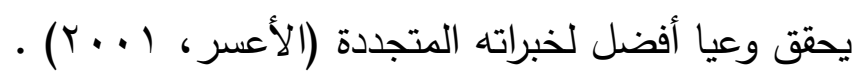
لذا فقد عرف فيجوتسكي حيز النمو المدكن بأنه المسافة بين مستوى النمو الفعلي الذي يحدد بحل المشكلات بشكل مستقل، ومستوى النمو المككن الذي يحدد من خـلال حل بل

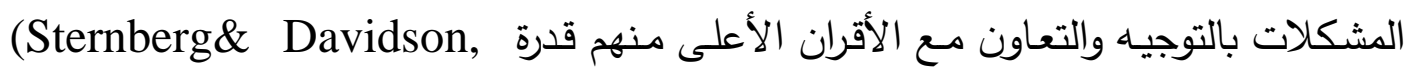
2005; Clabaugh,2010; Marsh\& Ketterer, 2010) كما أن الوسيط هو أداة (عادة ما يكون راثداً) أحد الوالدين أو المعلم يكثف ويعلم المتعلم

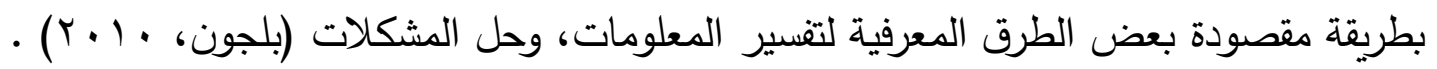
ومن ثَّم لابد من وجود أربعة صفات في التفاعل الذي يتم بين الوسيط والمتعلم لتكون عملية

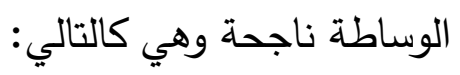
• التعمد : يركز الوسيط على مساعدة المتعلم على فهم كيف يستخدم عقله.

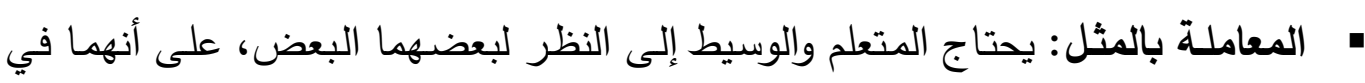
نفس المستوى، وهذا يعني أن الوسيط لا يدعي معرفة كيف يفكر المتعلم.

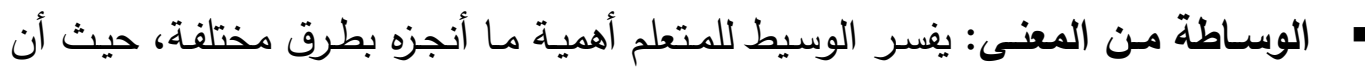

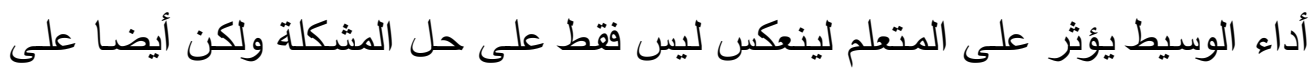
كيف تم الحصول على الحل وتعميم ذلك على المشكلات التي تتبثق منه.

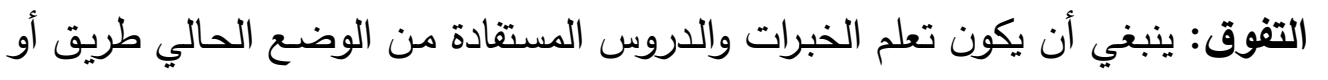
جسر لحالات جديدة. فيختلف البشر من فرد لآخر في الطريقة التي يستطيعون من

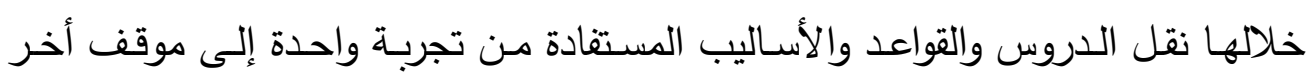
• (González et al., 2008)

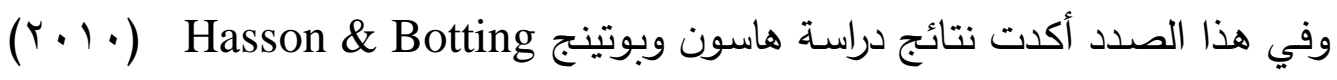
على أن أسلوب التقييم الدينامي المعرفي يسهم في إحداث تغييرات متباينة في تعليم قواعد اللغة للأطفال ذوي الإعاقات اللغوية. 
وترتكز عملية التعلم الوساطي على مجموعة من الإستراتيجيات التي يمكن أن يستعين بها الوسيط (الأكثر قدرة) أثناء القيام بعملية التقييم الدينامي، وذلك للسعي نحو تطوير قدرات وإمكانات الأطفال العقلية، وللمساعدة في تغيير سلوك الأطفال بما يتتاسب مع الموقف، وكل ذلك

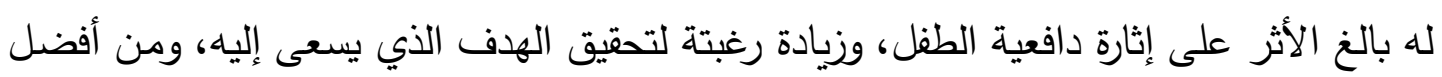

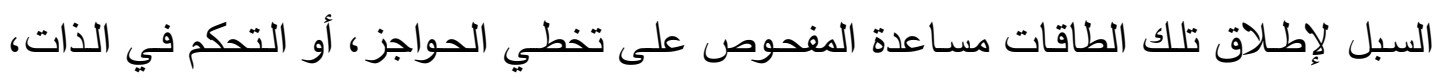
ومساعدته أيضًا على معرفة واقع وقيمة التقييم، واستدعاء مبدأ المتعة والألم. السبب وراء عزوف الباحثين عن التقييم الدينامي هناك أربعـة أسباب رئيسـة تكمن وراء عزوف البـاء عن الباحثين عن استخدام التقييم الدينامي في التشخيص ويمكن تلخيصها فيما يلي: 1- ميل علماء النفس للاختبارات التقليدية عن الاختبارات الدينامية. r- إدارة الاختبارات الدينامية معقدة، بالمقارنة بإدارة الاختبارات التقليدية. r- هناك عدد من الطرق المختلفة والمعقدة لتحليل الاختبارات الدينامية السيكومترية، ولكن لا يوجد طريقة واحدة مقبولة عالميًا.

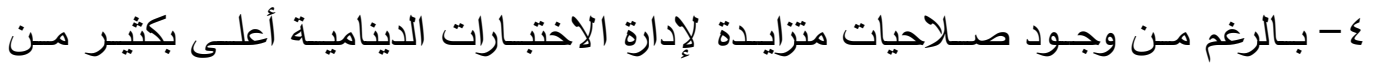
الاختبارات التقليدية، إلا أنها لا توضح كم شخص يستطيع أن يعتمد على الاختبارات

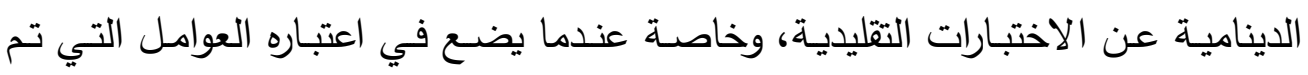
ذكرها بأعلى (2000, Lidz \& Elliott) •

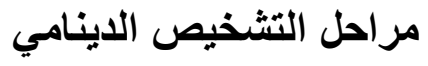
هناك نوعان من التثييم الدينامي أحدها طويل الأمد والثاني قصير الأمد، ففي المرحلة

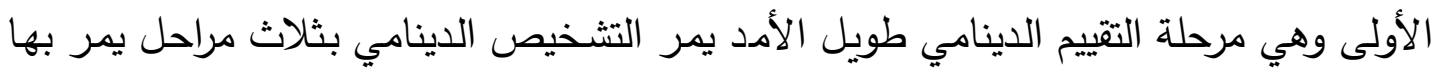
الكفحوص سيتم التعرض لها في النقاط التالية: ا- مرحلة الاختبار القبلي: فحص الوضـع المعرفي عند المفحوص قبل استعمال عملية التعلم الوسـاطي من قبل الوسيط، ويهذف هذا النوع مـن التشخيص لتقويم الوضـع 
المعرفي الحالي للمفحوص والصعوبات التي تواجهه، وهذا يعني فحص وتقويم قدرة التعلم المخبأة لدى الطفل والطريقة المناسبة لتطويره.

r- مرحلـة التعلم الوسـاطي: حيث يعمل الفاحص على تحسين القدرات العقلية الضعيفة الموجودة عند الففحوص من خلال استعمال عملية التعلم الوساطي. r- الاختبـار البعدي: فحص الوضع المعرفي الخـاص بالدفحوص بعد استعمال عمليـة

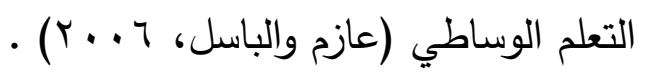

والطريقة الثانية من التقييم الدينامي والتي تسمى تقييم دينامي قصير الددى يمكن تتفيذها في جلســة واحدة، حيث يقدم اختبـار مماثل للاختبـارات التقليديـة ولكن مـع تقديم المســاعدة والتوجيهـ عند وجود صـعوبات، ولا يتم الانتقال عند مستوى أعلى إلا عند حل جميع أسئلة المستوى الأدنى، إما إذا لم يتم حل الصعوبات في هذا المستوى فيقدم للطفل مزيد من المساعدة

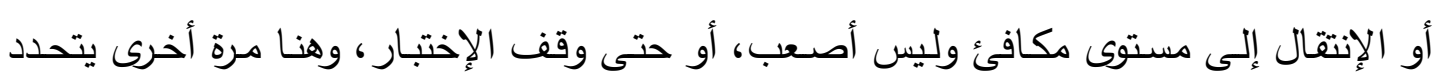

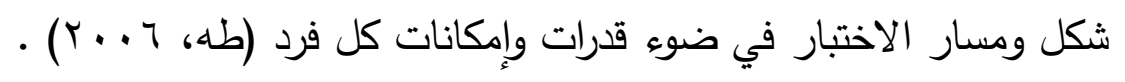

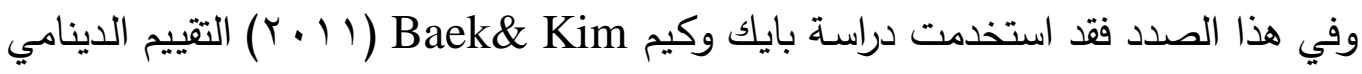
طويل الأمد، وقد أظهرت نتائج الدراسة أن تعليمات التتييم الدينامي لها تأثير كبير على تعلم الأطفال لكفاهيم العدد مع حالة طفل يبلغ (ء) سنوات من العمر ، ولذلك أوصت الدراسة بأهمية

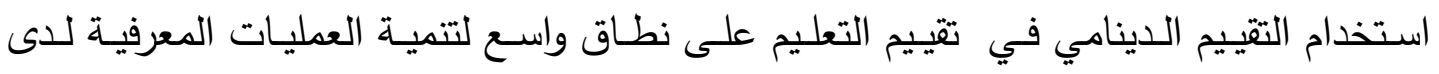

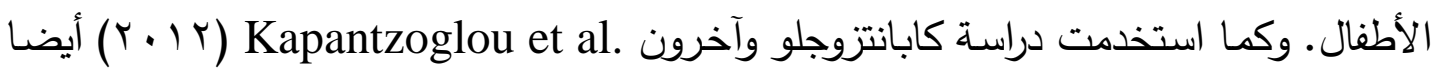
التثييم الدينامي طويل الأمد من خـلال اختبار قبلي، يتبعهـ دورة تعليم مهارات اللغة، ثم يليه

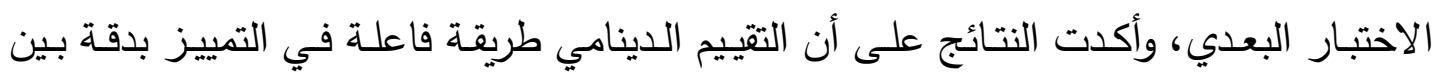
الأطفال الذين يعانون من إضطرابات في اللغة. 


\section{جدول رقم (1) (1)}

الفرق بين التقييم التقليدي و التقبيم الدينامي المعرفي

\begin{tabular}{|c|c|c|}
\hline الעها & & г \\
\hline 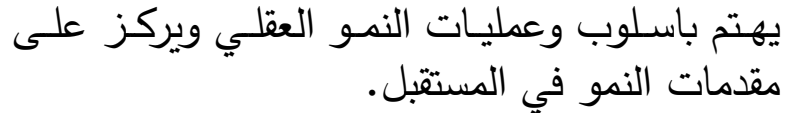 & 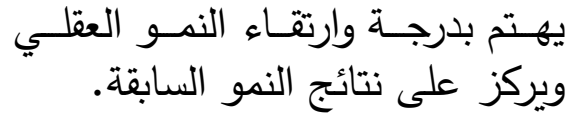 & 1 \\
\hline 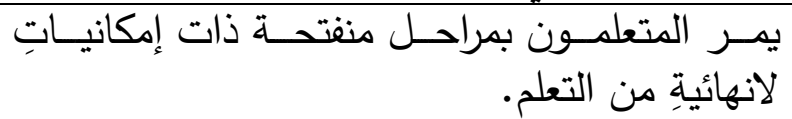 & المتعلمون بمراحل محددة مسبقا & T \\
\hline آداء الطفل بنفس & معياريـة & r \\
\hline 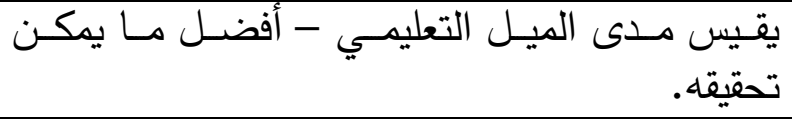 & مع الحـــالي للشــــ & $\varepsilon$ \\
\hline & 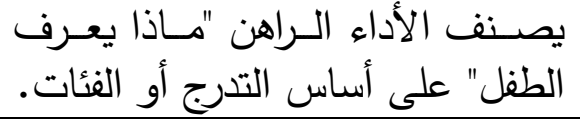 & 0 \\
\hline 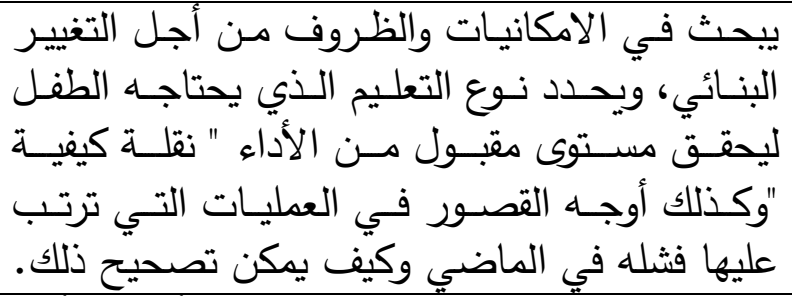 & ill & 7 \\
\hline يبحـث عـن مؤشـرات التطور والتتميـة وأقصىى أداء & سائص والوظ المستبلي على أسـاس العقلية. & V \\
\hline 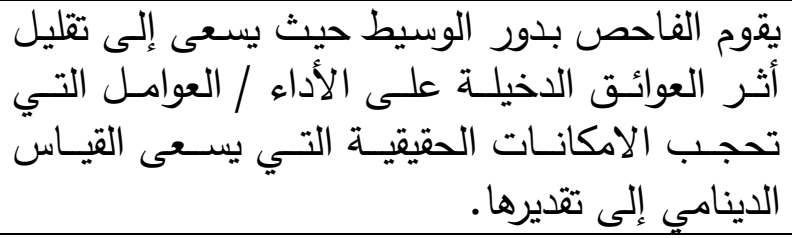 & 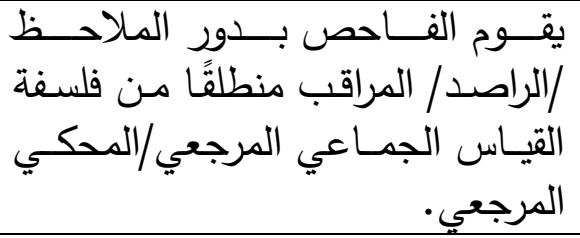 & $\Lambda$ \\
\hline والهــدف منـــه هـو : التشــيص تمهيـدًا للتخطــيط & 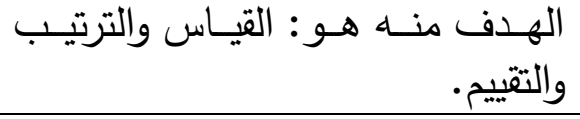 & 9 \\
\hline يتدخل الفاحص في عملية التقييم & 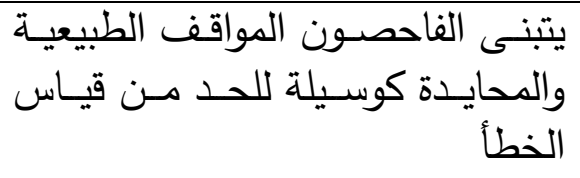 & 1. \\
\hline 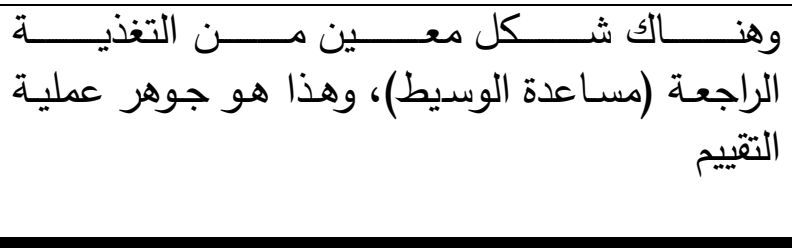 & 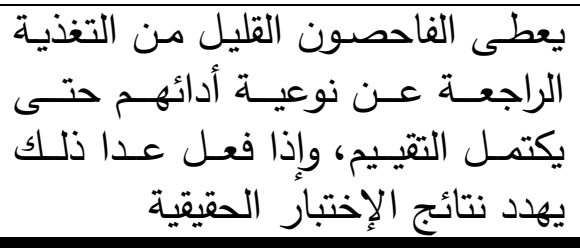 & 11 \\
\hline
\end{tabular}

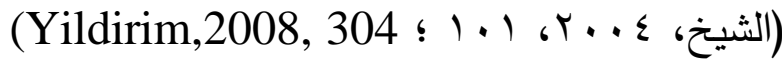


Gutiérrez-Clellen \& وفي هذا الصدد، فقد هدفت دراسة جويتريز - كليلن وبينا Peña التقليدي الموحد مـع الأطفال المختلفين في الثقافـة واللغـة، وقد أظهرت النتائج قدرة التقييم الدينامي على التمييز بين الأطفال ذوي اضطراب اللغة، والتعرف على إمكانات الطفل للتعلم الممكن. وقد حاولت دراسة حسانين (Y + ب) التحقق من فاعلية التثييم الدينامي في تقييم أداء الأطفال الموهوبين والعـاديين وذلك بالنسبة لبعض العمليـات المعرفيـة المتمثلـة في عمليـات التخطيط والانتباه وعمليـة المعالجـة المتزامنـة والمعالجـة المتتابعـة، وأشـارت النتائج الـى وجود فروق دالة إحصائية عند مستوى دلالة ( (...) بين متوسطي درجات الأطفال الموهوبين في الأداء بـالمنحى التقليـدي مقارنـة بـالأداء بـالمنحى الدينامي في الدرجـة الكليـة وفي درجـات العمليات المعرفية الأربعة ( PASS) التخطيط، والانتباه، وعملية المعالجة المتزامنة، والمعالجة المتتابعة لصالح الأداء بالمنحى الدينامي. لقد كان هناك العديد من المناحي والنظريات الأخرى غير فيجوتسكي وفيرشتين تسعى نحو تطور أساليب التقييم نتيجة الازدياد المطرد للحاجة إلى تغير النمط التقليدي في عملية التقييم، وإيجاد نوع بديل يتواءم مـع التطور العلمي، والقفزة التكنولوجية الكبيرة، التي جعلت من العالم الواسـع قريـة صغيرة يمكن اجتيازهـا في وقت قصير ، جهد قليل، مما سهل الانفتاح العالمي

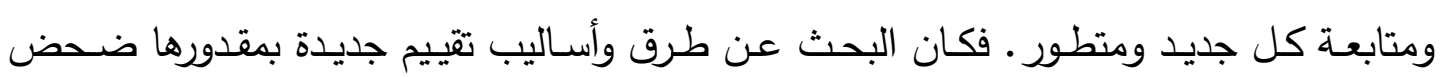
الأساليب القديمة الجامدة، والرقي بعملية التقييم إلى أفضل مستوياتها، وقد كان هناك العديد من المناحي والنظريات الأخرى التي تتاولت التتييم الدينامي على مر العصور يمكن تلخيصها فيما يلي، انظر الجدول (r) التالي. 


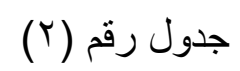

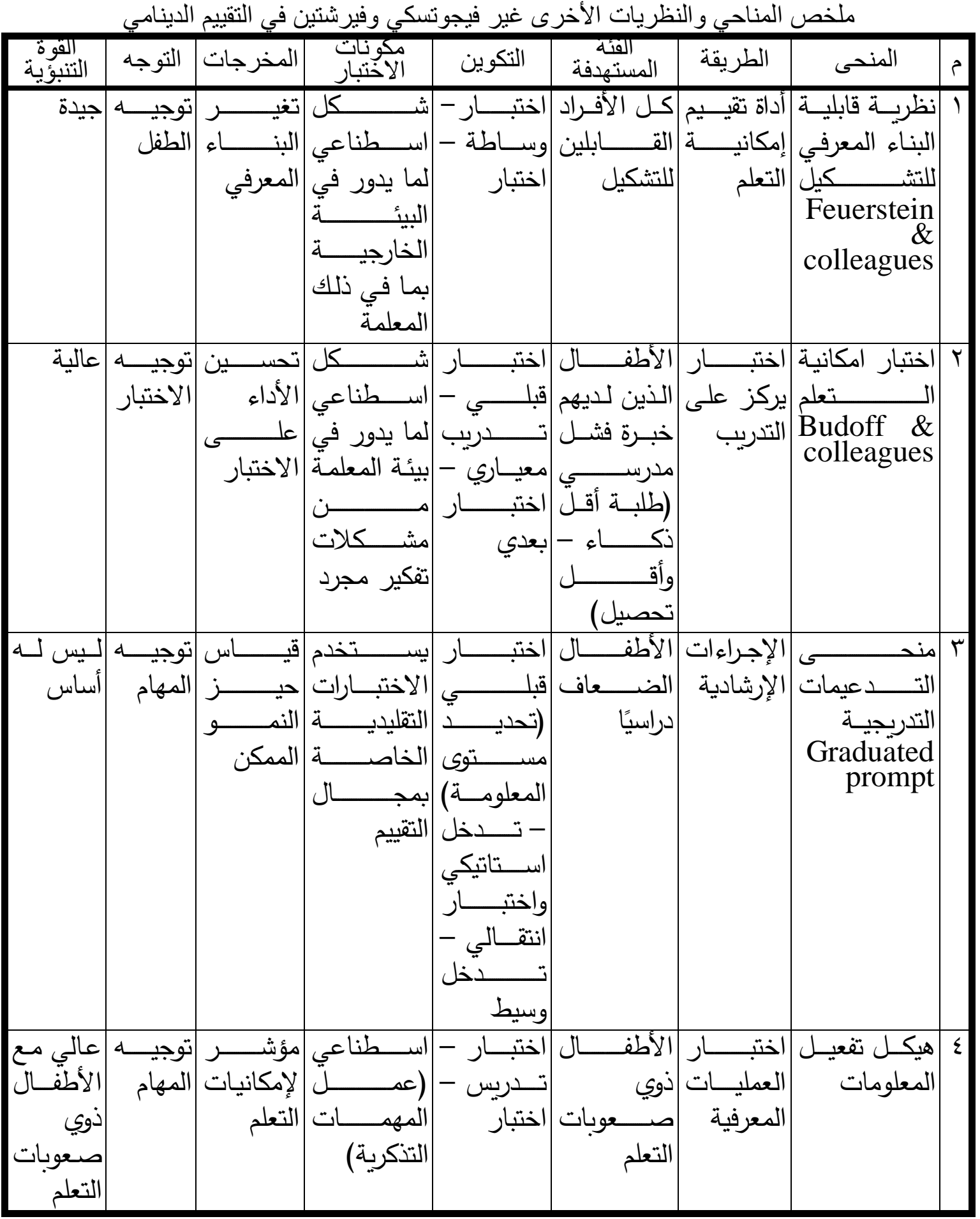

(Sternberg \& Grigorenko, 2002, 24-26) 


\section{Learning Disabilities}

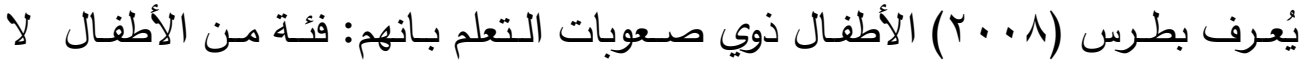

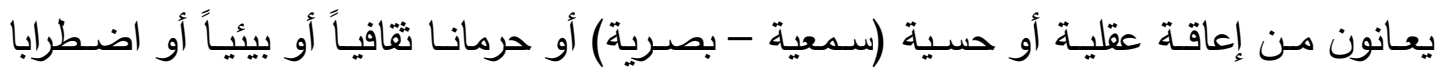

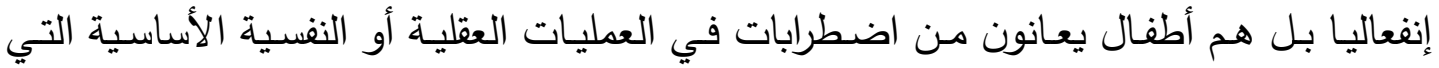
تشمل الانتباه، والإدرالك، وتكوين الدفهوم، والتنكر ، وحل المشكلات يظهر صداه في عدم القدرة

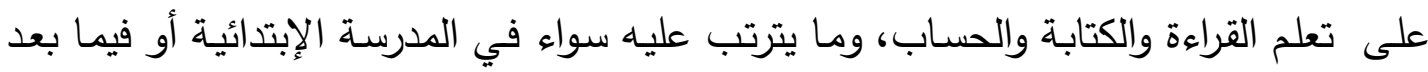

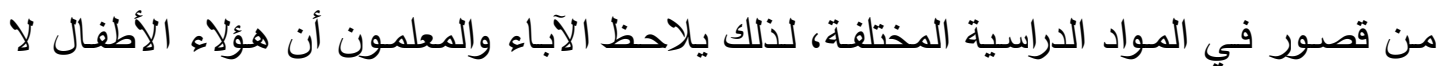

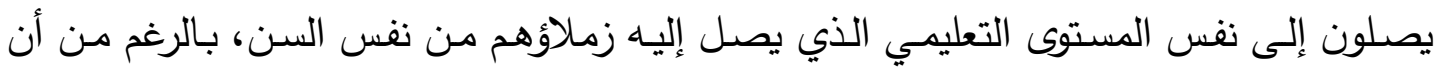
لايهم قدرات عقلية ونسبة ذكاء متوسطة أو فوق المتوسطة. ويرى عامر ( 9. . Y، Y T) أن " مصطلح يشمل الأطفال الأسوياء من حيث القدرات

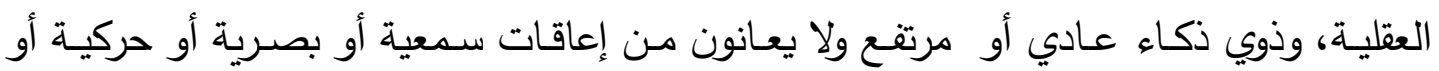

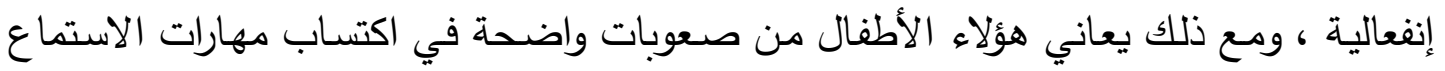
أو القراءة أو الكتابة أو آدء العمليات الحسابية ".

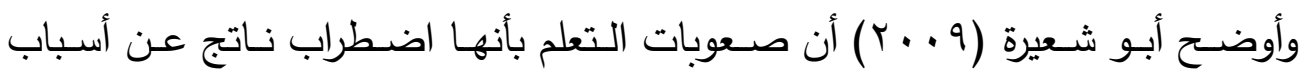

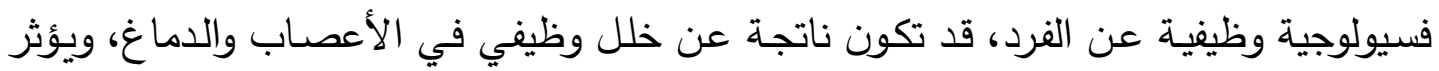
الاضطراب على قدرات الفرد العقلية بحيث تؤثر على تحصيله الأكاديمي في مجال مهارات القراءة والكتابة والتهجئة والمهارات العددية Counting Skills ، ولا يرجع السبب إلى إعاقة عقلية أو حسية Mental or Sensory مع ملاحظة تباين Difference بين القدرة العقلية وأداء الفرد الأكاديمي.

وبالتالي، فصعوبات التعلم النمائية هي نقص في المهارات التي يختارها الطفل والتي تتعلق

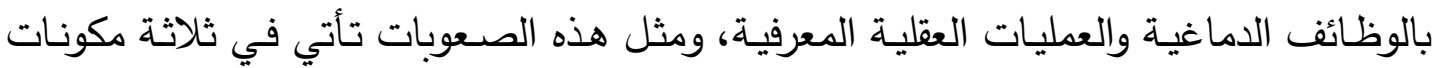

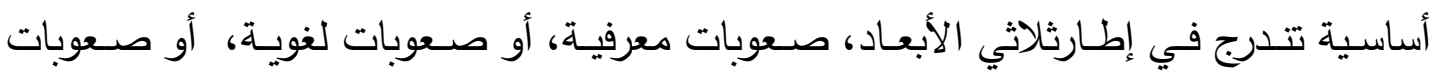

$$
\text { بصرية - حركية وذلك على النحو التالي: }
$$

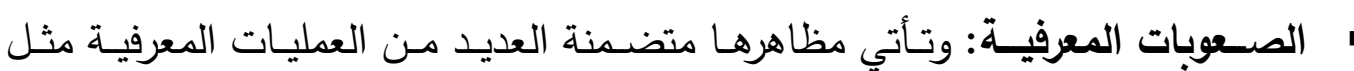
(صعوبات الانتباه، والإدراك،، والذاكرة. حيث أنها هي التي تؤثر على التمييز، وتشكيل

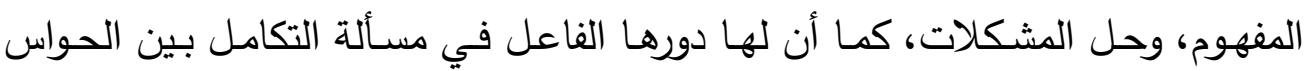


أيضاً. وبذلك نجد أنها قد تتركز أصلاً في ثلاث عمليات عقلية معرفية أساسية إلى جانب بعض الأمور الأخرى التي تتعلق بها.

الصعوبات اللغويـة: وتتمثل مظاهرها في (اللغة الثفوية، والتنكير السمعي، والإستقبال

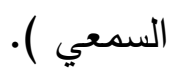

الصعوبات البصرية - الحركية: وتتمثل مظاهرها في (أداء مهارات حركية كبيرة تعكس

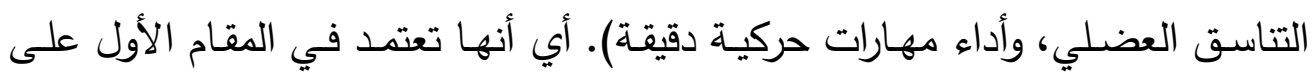

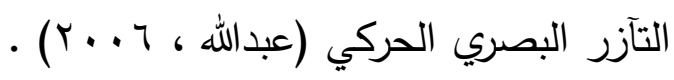
تصنيف صعوبات التعلم نظراً لتعدد واختلاف التعريفات التي تم تقديمها لمفهوم صعوبات التعلم سواء من قبل هيئات أو أفراد، فقد ظهرت بناء على ذلك العديد من التصنيفات التي تعد وسيلة هادفة نحو تسهيل

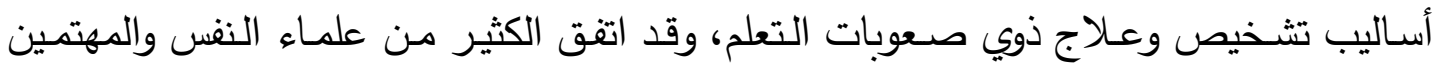
بهذا المجال إلى تصنيف صعوبات التعلم إلى مجموعتين:

Developmental Learning Disabilities صعوبات التعلم النمائية

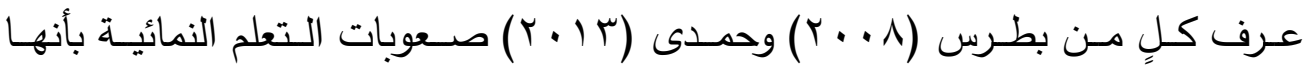

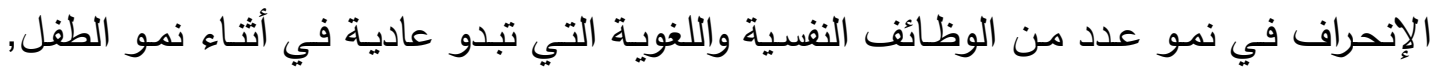

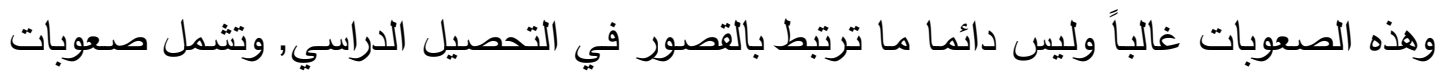

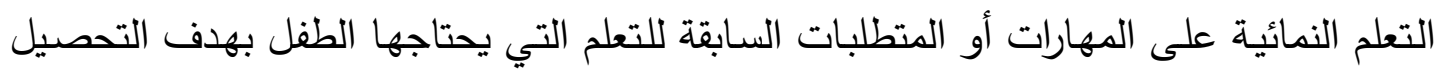

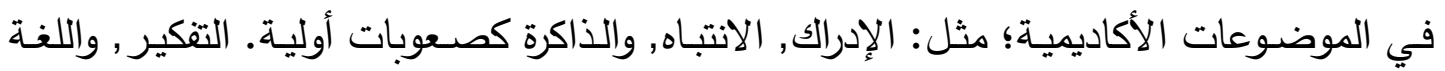

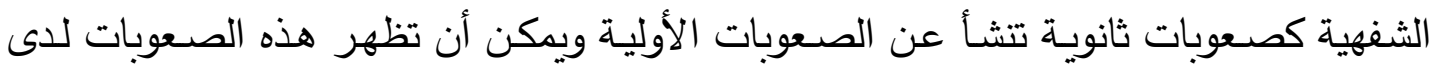
الطفل قبل سن دخول المدرسة.

Academic Leaning Disabilities صعوبات التعلم الأكاديمية

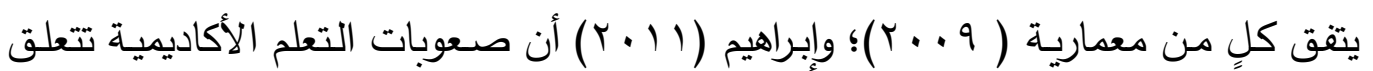
بالموضوعات الدراسية الأساسية مثل صعوبة القراءة، وصعوبة الكتابة، وصعوبة إجراء العمليات

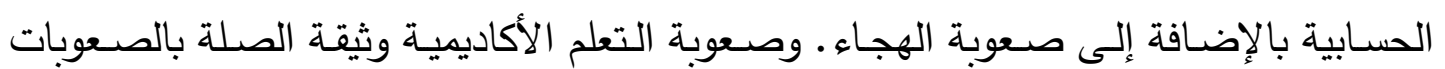
النمائية وتتتج عنها. الأطر التفسيرية لصعوبات التعلم 
يفترض هذا الاتجاه أن السبب فى حدوث صسوبات التعلم لا يكون دائمـاً نابعـاً من

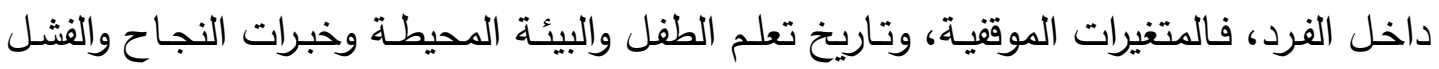

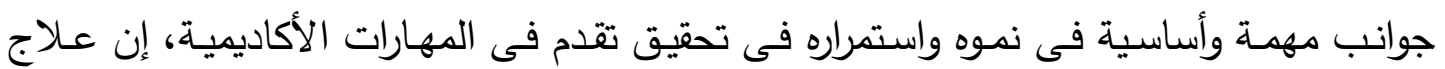

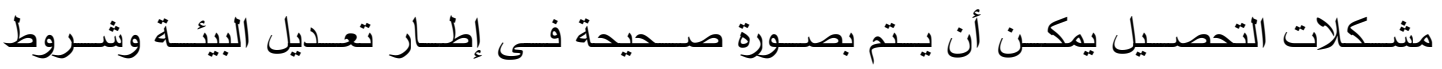

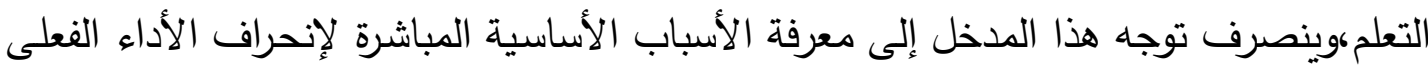

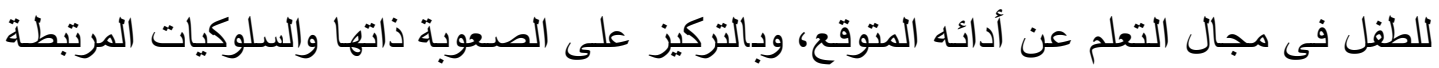
بها، وبالتالى فإن التمركز يكون حول الطفل من خلال إعداد البرامج الفردية للعلاج لا الاعتماد على بعض التعميمات المحددة مسبقاً (الزيات، 9 . . r). الفكرة الرئيسية هنا هى نضج المهارات الإدراكية التى يتبعها سلسلة من التتابعاتهوقدرة

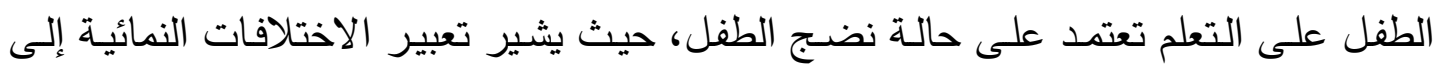
بطء فى سمات معينة من النمو، وطبقاً لوجهة النظر هذه فإن كل فرد لديه معدل نمو للوظائف الفي

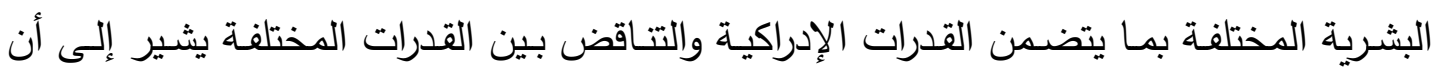

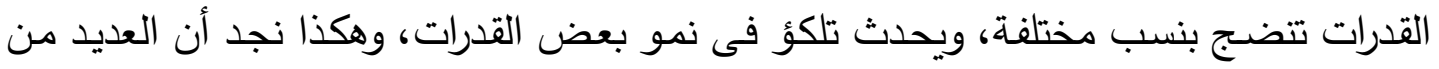

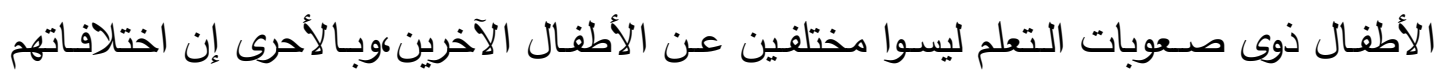

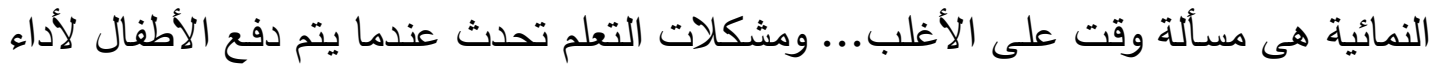

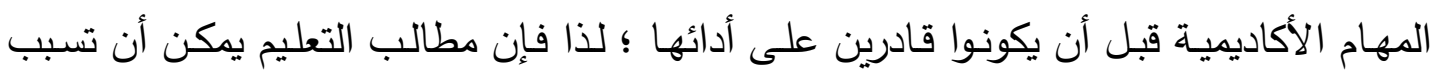

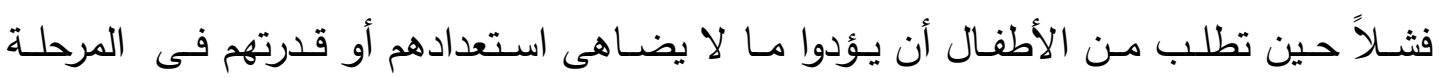

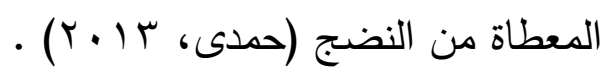

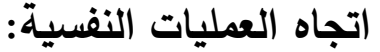

يشير هذا الاتجـاه إلى أن التجهيز العقلى للمعلومـات يعتمد على العمليـات الإدراكيـة

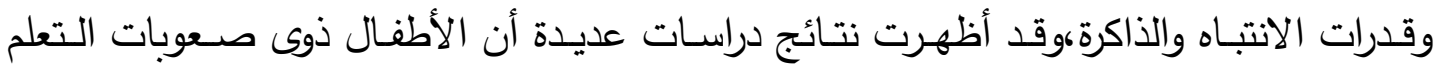
يعانون من قصور فى عملية الانتباه أكثر من أقرانهم العاديين، وأن صعوبات التعات التعلم هى حالة التهات

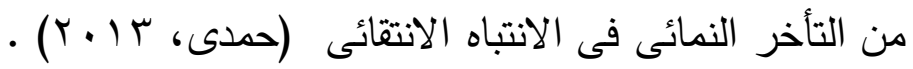

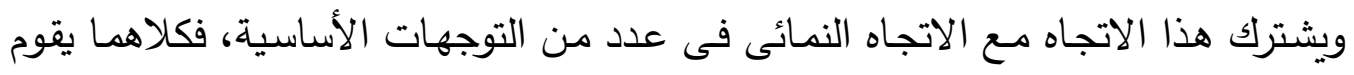
على افتراض وجود قوانين نمائية تحكم نمو وتكامل وتعاقب هذه المنظومات أو المتتابعات من هن الأن 
السلوك،وكلاهما يفترض أن حدوث أى انحـراف أو خلل أو اضطراب فى هذا التتابع أو فى معدله أو هما معًا يقود إلى مشكلات تعبر عن نفسها فى اضطراب السلوك أو انحرافـه أو تباعده عن السواء، وفى بعض الحالات إلى عدم قدرة الفرد على الأداء فى مجال نشاط القدرة، وعلى ذلك يبدو اتجاه العمليات النفسية مشابهًا للاتجاه النمائى باعتبارهما اتجاها واحدًا (الزيات، $\cdot(r \cdot .9$

\section{الاتجاه المعرفي}

ينطلق هذا الاتجاه من أن التعليم نوع من أنواع النشـاط العقلى المعرفى، ومن ثم يتأثر بالمحـددات المعرفيــة المتمثلــة فـى المعرفـة الســابقة، وأســاليب اكتســابها، والاحتفــاظ بهــا، واستخدامها، واستراتيجيات استخدامها، وأن ذوى صعوبات التعلم يختلفون من حيث الكم والكيف عن العاديين من حيث الحصيلة اللغوية والمعرفية من المفاهيم أو البنية المعرفية والاستراتيجيات المعرفية وفاعليات استخدامها، وسعة ونظم تجهيز ومعالجة المعلومات، وفاعلية الذاكرة العاملة،

$$
\text { وفاعلية أو كفاءة التمثيل المعرفي (الزيات، } 9 \text {. . ب) . }
$$

ويركز هذا الاتجاه على العمليات الإنسانية فى التعلم والتفكير والمعرفة حيث أن القدرات المعرفية عبارة عن فروع من المهارات العقلية الضرورية للوظائف البشرية، وهى تمكن الفرد من

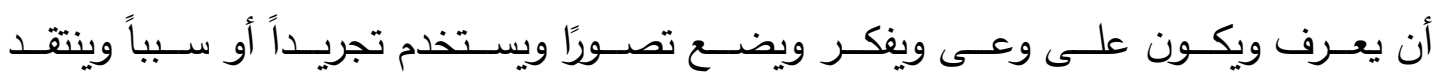
ويبتكر ،ويتحدث هذا الاتجـاه عن نموذج تجهيز / معالجـة المعلومات،وهو نموذج للتعلم يؤكد على تدفق المعلومات داخل عقل الشخص وأنظمة الذاكرة (حمدى، با ـ ب) .

\section{الاتجاه متعدد الأبعاد}

لا يكتفى هذا الاتجـاه فى تفسير صعوبة التعلم بوجود سبب واحد لها،حيث يرى فى ذلك قصورًا فى رؤية صعوبات التعلم وتقييمها وعلاجها؛ ولذلك فإن هذا الاتجاه يقترح فروضًا فرعية متعددة لها، وذلك من خلال الاتجاهات السابقة جميعاً،وهذه النظرة هى الأشمل والأعم والأكثر تكاملاً، وهى الأمثل فى تتاول صعوبات التعلم (عبدالله، ج . . Y) . 
1-توجد فروق ذات دلالة إحصائية بين متوسطات درجات الأطفال ذوي صعوبات التعلم

النمائية في كل من التقييم الدينامي والتقييم التقليدي بالنسبة لبعض العمليات المعرفية (عمليات التخطيط والانتباه وعملية المعالجة المتزامنة والمعالجة المتتابعة) وذلك في لي لئي

$$
\text { اتجاه التقييم الدينامي. }
$$

ץ-توجد فروق ذات دلالة إحصائية بين متوسطات درجات الأطفال ذوي صعوبات التعلم النمائيـة ومتوسـطات درجـات الأطفـال العـاديين وذلـك على مقيـاس التقيـيم الـدينامى للعمليـات المعرفيـة (عمليـات التخطيط والانتبـاه وعمليـة المعالجـة المتزامنـة والمعالجـة المتتابعة) في اتجاه الأطفال العاديين.

$$
\text { الولًا: هنهج الدراسة والإجراءات }
$$

استخدم الباحثة المنهج الوصفي المقارن، والذي يعتمد على وصف الفروق بين مجموعتى

$$
\text { الدراسة (الأطفال ذوي صعوبات التعلم النمائية والأطفال العاديين). }
$$

$$
\text { ثانياً: عينة الدراسة }
$$

$$
\text { تكونت عينة الدراسة من مجموعتين على النحو التالي: }
$$

• مجموعة الأطفال ذوي صعوبات التعلم النمائية: عينة مكونة من (ro) طفلاً من ذوي صـعوبات التعلم النمائيـة الملتحقين بالمستوى الثاني في مرحلـة ريـاض الأطفـال مـن مدرسة النيل بالعمرانية بمحافظة الجيزة.

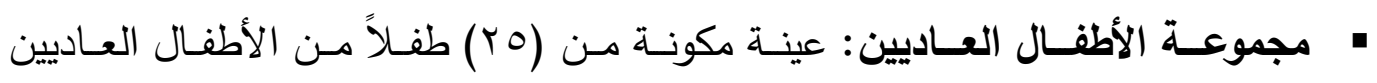
الملتحقين بالمستوى الثاني في مرحلـــــــــاض الأطفـال مـن مدرسـة النيـل بالعمرانيـة

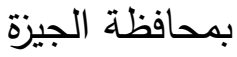
ويمكن توضيح كافة المعلومات المتعلقة بعينة الدراسة على النحو التالي: 


$$
\text { أ) شروط ومو اصفات العينة }
$$

ا- أن يكـون أفراد العينـة مـن الأطفال الملتحقين بالمستوى الثاني مـن ريـاض الأطفـال

KG.II

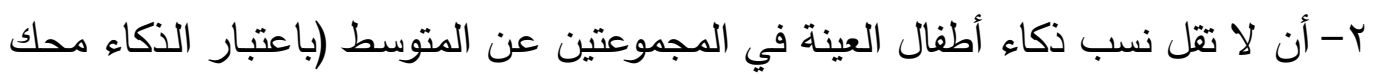

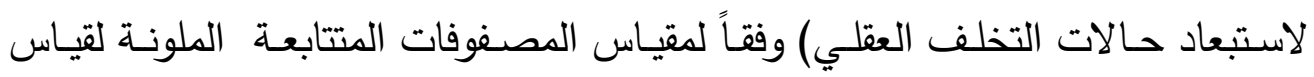
ذكاء الأطفال تأليف (جون رافن). ب- ألا تضم العينة أطفالاً يعانون من أي مشكلات أو إعاقات (نمائية - عقلية - حسية -

$$
\text { ع - انتظام أفراد العينة في أو غيرها أو يعانون من مشكلات صحية واضحة (عضوية - نفسية). }
$$

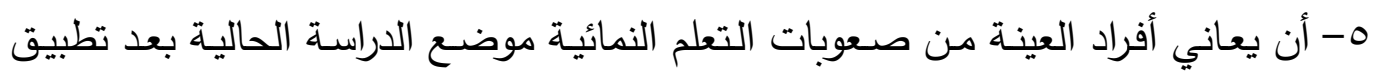
مقياس صعوبات التعلم النمائية عليهم وفقاً للأدوات المستخدمة في الدراسة.

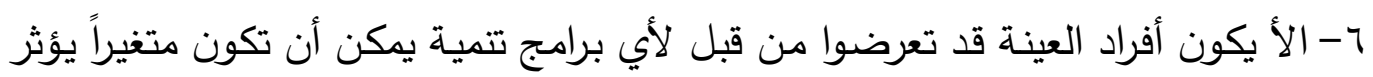

$$
\text { ب) خطو ات نتائج التقييم الدينامي لتينار العينة }
$$

1- اختيار الروضة التي طبقت بها الدراسة وهي مدرسة النيل بالعمرانية. r- اختيار عينة الدراسة من الأطفال ذوي صعوبات التعلم النمائية من بين جميع الأطفال

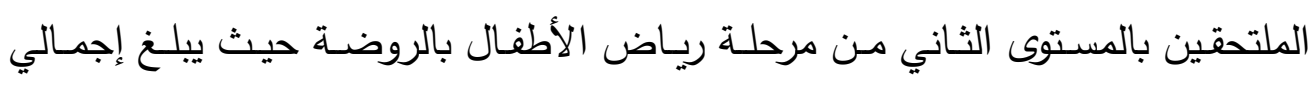
الأطفال في مدرسة النيل (OV9) طفلاً. r- تم استبعاد الأطفال المعاقين والمصابين بأمراض صحية أو حسية أو حركية. ع- تم تطبيق اختبار المصفوفات المتتابعة للذكاء كمحك للاستبعاد ومقياس صـوبات

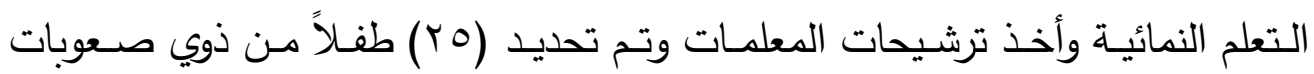

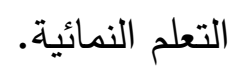
ه- قامت الباحثة بالتجانس بين أطفال العينـة مـن المجموعتين (الأطفال ذوي صـوبات التعلم- الأطفال العاديين) من حيث العمر ، والذكاء. 


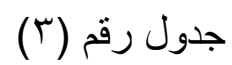

يوضح دلالة الفروق بين الأطفال ذوي صعوبات التعلم النمائية والأطفال العاديين بالنسبة لمتغير

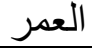

\begin{tabular}{|c|c|c|c|c|c|c|}
\hline اتجاه الدلالة & مستوى الدلالة & قيمةت & $\varepsilon$ & 5 & ن & المجمو عات \\
\hline \multirow{2}{*}{ غير دالة } & \multirow{2}{*}{ غير دالة } & \multirow{2}{*}{ - . } & .. & $0 . r$ & ro & الأطفال ذوي صعوبات التعلم \\
\hline & & & Tr & 0.7 & ro & الأطفال العادين \\
\hline
\end{tabular}

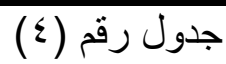

يوضح دلالة الفروق بين الأطفال ذوي صعوبات التعلم النمائية والأطفال العاديين بالنسبة لمتغير

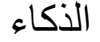

\begin{tabular}{|c|c|c|c|c|c|c|}
\hline اتجاه الدلالة & مستوى الدلالة & قيمة ت & $\varepsilon$ & 5 & ن & المجمو عات \\
\hline \multirow{2}{*}{ غير دالة } & \multirow{2}{*}{ 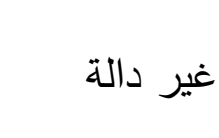 } & \multirow{2}{*}{. $.1 \mathrm{r}$} & $1 . .1 r$ & 110.1 & ro & الأطفال ذوي صعوبات التعلم \\
\hline & & & V.r & 117.1 & ro & الأطفال العادسن \\
\hline
\end{tabular}

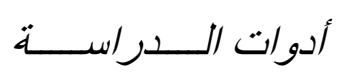

1 - اختبار المصفوفات المتتابعة الملون للأطفال لر افن (إعداد : محمد الخطيب)

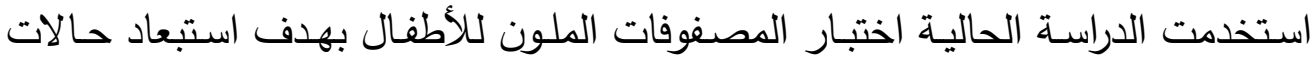
التخلف العقلي ولتجانس العينة من الأطفال ذوي صعوبات التعلم النمائية في المرحلة العمريـة

$$
\text { من 0-7 سنوات. }
$$

$$
\text { وصـــف الاختـــار }
$$

تتكون المصفوفات المتتابعة الملونـة من ثلاثة أقسام هي (أ)، (أب)، (ب) يشمل كل

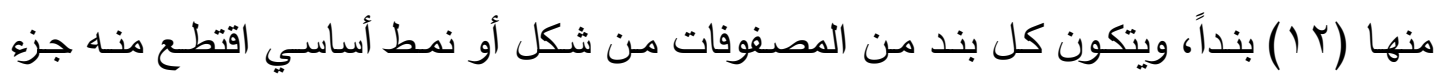
معين، وتحتهـ سـتة أجزاء يختـار مـن بينها المفحوص الجزء الذي يكمل الفراغ في الثكل الأساسي.

وقد استخدمت الألوان كخلفية للمشكلات لكي تجعل الاختبار أكثر تشويقا ووضوحا وإثارة لانتباه الأطفال.

وتعتمد مشكلات القسم الأول (أ) على قدرة الفرد على إكمال الأنماط المستمرة، وقرب نهاية المجموعة بتغير نمط الاستمرار على أساس بعدين في نفس الوقت. 
ويعتمد النجاح في قسم (أب) على قدرة الفرد على إدراك الأشكال المنفصلة في نمط الأنسان

كلي على أساس الارتباط المكاني.

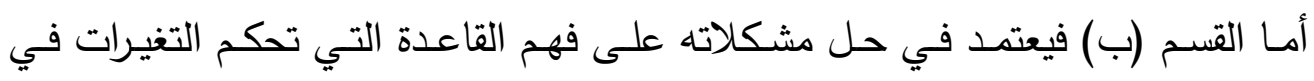

الأشكال المرتبطة منطقيا أو مكانيا وهي تتطلب نمو قدرة الفرد على التفكير المجرد. الخصائص السيكومترية لاختبار المصفوفات المتتابعة الملون للأطفال

صــــ الاختبـــار

Raven; Court \& ～） ورافن وكورت ورافن كورت (Court, 1980)

Raven, 1977 الدراسـات الاجنبية العديدة التي اجريت لتقدير صدوق اختبار المصفوفات

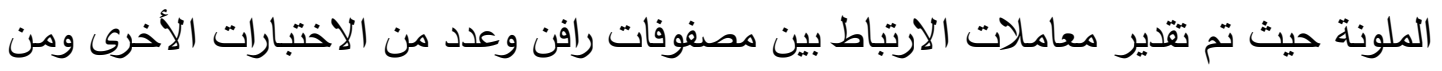

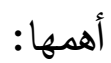

اختبار وكسلر للأطفال (القسم اللفظي حيث تراوحت معاملات الارتباط بين (اس. . )

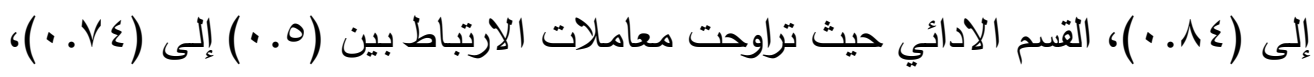

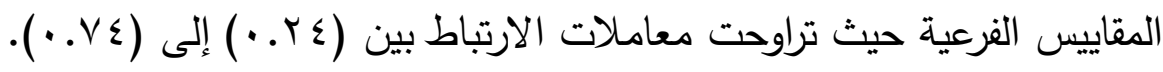

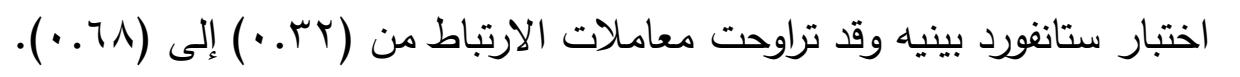

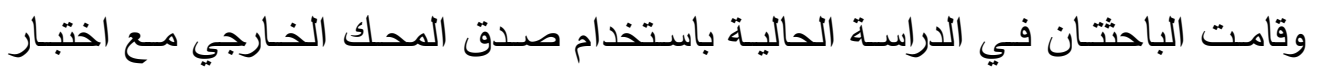

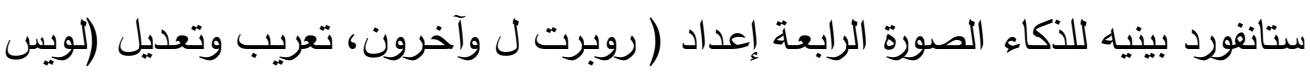

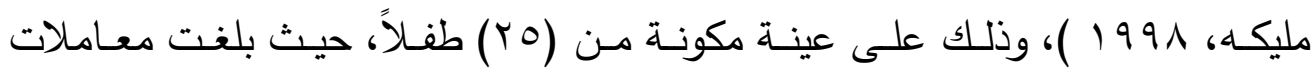

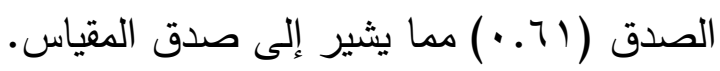

ثبــات الاختبــار

أورد كل من كورت (Court, 1980) ورافن وكورت رافن ( Raven; Court \&

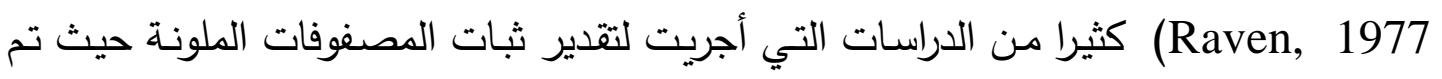

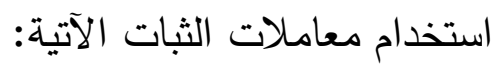

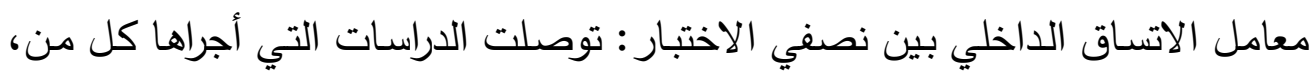

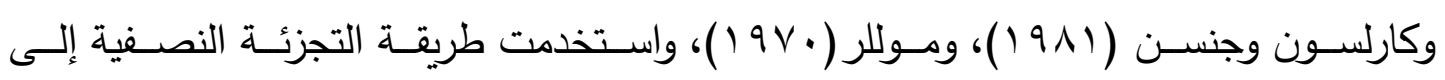

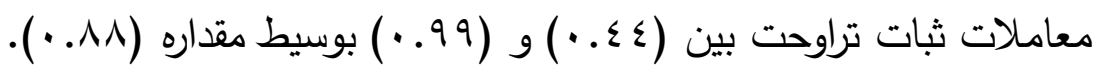


وفي الدراسـة الحالية تم حساب معامل الثبات عن طريق إعادة التطبيق على عينـة من

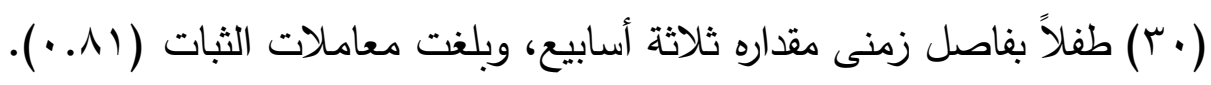

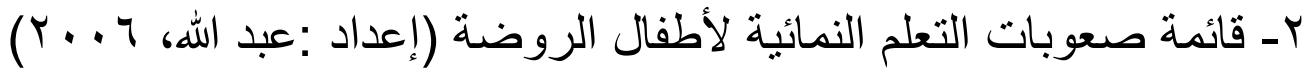
الهدف من المقياس

يهدف هذا المقياس إلى التعرف على صعوبات التعلم النمائية التى يمكن أن يتعرض لها الأطفال فى مرحلة الروضة، و تحديدها،و قياسها.

وصف المقياس

يمثل هذا المقياس قائعـة بأهم صـعوبات التعلم النمائيـة لأطفال الروضـة، ويضـم المقيـاس

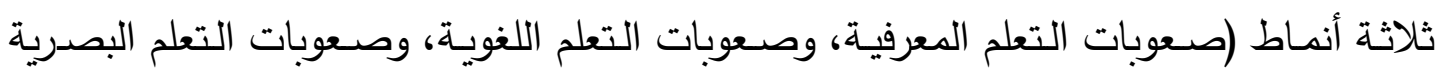

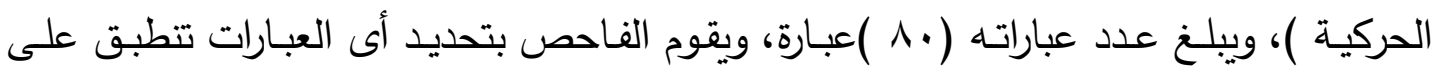

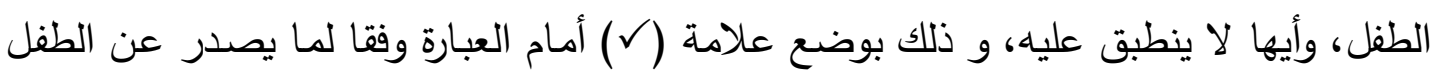

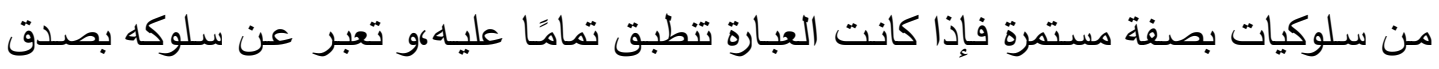

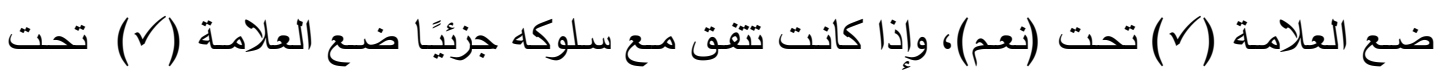

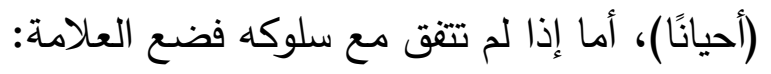

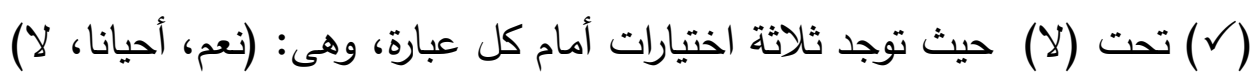

تصحيح المقياس

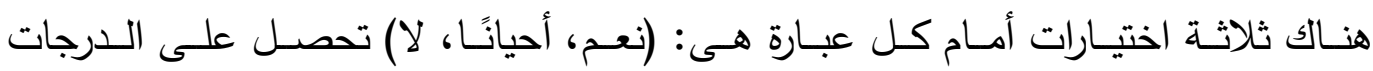

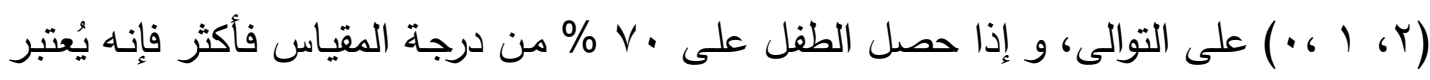
آنذاك ممن يعانون من صعوبات التعلم. الخصائص السيكومترية للمقياس

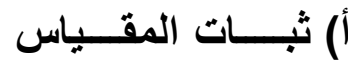
قام معد الدقياس بحساب ثبات المقياس عن طريق التجزئة النصفية، وبطريقة كرونباخ

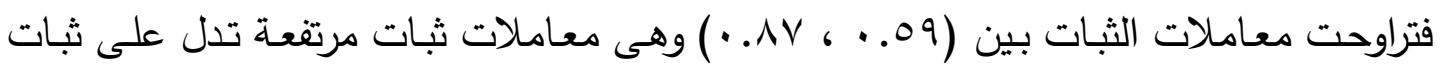

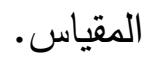


كمـا قامت الباحثتان في الدراسـة الحاليـة بإيجـاد معاملات الثبات بطريقة التجزئة النصفية بإيجاد معامل الارتباط بين نصفى المقياس ثم إيجاد معامل الثبات للمقياس ككل كما يتضـح فى مي

جدول (0)

جدول (0)

معاملات الثبات بطريقة التجزئة النصفية

\begin{tabular}{|c|c|c|}
\hline معامل الثبات ككل & معامل الارتباط بين نصفى & الأبعاد \\
\hline. .19 &..$\wedge 1$ & صعوبات الانتباه \\
\hline.$\wedge \wedge$ &.$\vee v q$ & صعوبات الإدراك \\
\hline..$\wedge 7$ &.$V 7$ & صعوبات الذاكرة \\
\hline$. .9 \leq$ &. .19 & صعوبات التفكير \\
\hline .9 . &. .10 & صعوبات اللغة \\
\hline. .91 &..$\wedge \varepsilon$ & صعوبات بصريـة حركية \\
\hline .94 &..$\wedge 7$ & الدرجة الكلية \\
\hline
\end{tabular}

يتضح من جدول (0) ارتفاع قيم معاملات الثبات ؛ مما يدل على ثبات الاختبار.

ب) صدق المقياس

قام معد المقياس بحساب صدق المقياس بأربع طرق: صدق المحتوى، وصدق المحكمين،

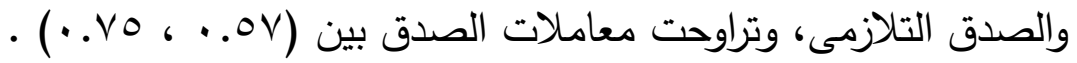

ثم قامت الباحثتان في الاراسـة الحاليـة بإيجاد معـاملات الصـدق، والثبات لقائمـة صسوبات التعلم النمائيـة لأطفـال الروضــة على عينـة قوامها (Y0) طفـلا لإيجـاد معـاملات الصـدق،هع

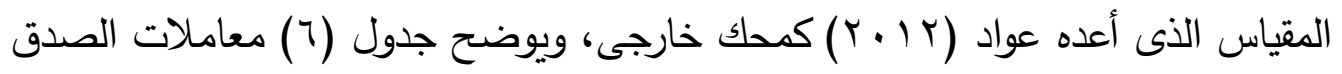
جدول (7)

الصدق التلازمى لقائمة صعوبات التعلم النمائية لأطفال الروضة

\begin{tabular}{|c|c|}
\hline معاملات الصدق & الأبعاد \\
\hline. .10 & صعوبات الانتباه \\
\hline.$\vee v q$ & صعوبات الإدراك \\
\hline.$V Y$ & صعوبات الذاكرة \\
\hline$\cdot . \wedge 1$ & صعوبات التفكير \\
\hline.$\wedge \varepsilon$ & صعوبات اللغة \\
\hline..$\wedge 7$ & صعوبات بصرية حركية \\
\hline . & الدرجة الكلية \\
\hline
\end{tabular}


يتضح من جدول (†) ارتفاع قيم معاملات الصدق مما يدل على صدق المقياس r- مقياس منظومة التقييم المعرفي م. ت. م (الكاس) للذكاء يقـدم هـذا المقيـاس أداة تشخيصـية تـوفرت لهـا الأسـس النظريـة والدقـة السـيكومترية والمصداقية فأساسه نظرية لوريا في البناء العقلي، والتي تستمد قيمتها العلمية من ارتكازها على البناء التشريحي للمخخ، أمسا الدقة السيكومترية فترجع إلى خطوات التقييم والتتنين التي توفرت للمقياس سواء في بناء وحداته واختيار صـلاحيته السيكومترية، أما مصداقيته التطبيقية فترجع للنتائج التي حققها كأداة تشخيصية تصلح للمرحلة العمرية من V-O ا سنة لتقييم أداء الأفراد الموهوبين والأفراد الذين يعانون من مشكلات في التخطيط والذين يعانون من اضطرابات انفعالية شديدة، وهؤلاء الذين يعانون من إصابات أو تلف بالمخ، وذوي صعوبات التعلم، وذوي اضطرابات الانتباه واضرابات النشاط الزائد، وذوي الإعاقة السمعية وكذلك الذهنية. وقد تم استخدامه في البيئة المصرية في عدد من الدراسات التي أثبت قدرة فائقة على التشخيص والتتبؤ تفوق غيره من مقاييس القدرة العقلية، كما أثبت قدرة على تحليل العمليات المعرفية اللازمة للنجاح في المواد الدراسية الختلفة، وقد تطورت تلك الأداة من خلال التكامل النظري والتطبيق العملي في مجال علم النفس المعرفي.

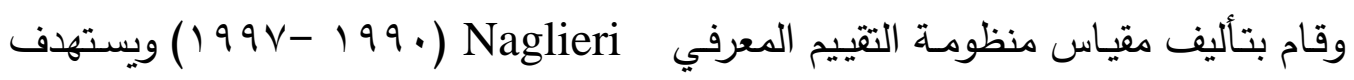
المقياس تقييم العمليات المعرفية للأطفال من سن (O - V V I الك المنظومـة التي تقوم على أسـاس نظريـة PASS للـذكاء وتعنـي (التخطـيط Alanning)، الانتبـاه Attention، التـآني

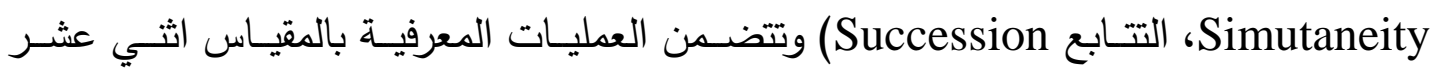
اختبارًا، وتعطي الاختبارات الفرعيـة درجـة مقاسـه (• ()، وانحراف معياري (ب)،وكل المقياس يعطي درجات متوسطها ( . . (1) وانحراف معياري (10). 
تم حساب ثبات الاختبار الفرعي من خلال طريقة التقييم النصفي لكل اختبارات التآني والتتابع، باستثناء اختبار معدل سرعة الكـلام مـن خـلال استخدام معـادلات سبيرمان وبرون، وطريقة إعادة الاختبار من طرق الثبات التي استخدم مع اختبارات التخطيط والانتباه واختبار تكرار معدل الكلام وهو أحد اختبارات التتابع وذلك لأن هذه الاختبارات تتضمن في مهامهات التهات تقدير زمني، ومعامل الثبات للبطارية الأساسية والدرجات الكلية تم حسابها من خـلال طريقة

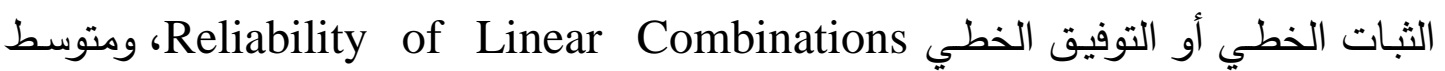
Fisher`z معامل الثبات للمجموعـة العمريـة لعينـة التقنيين تم حسـابها مـن خـلال طريقـة Transformation وقاعدة الثبـات تم تقديمها مـن خـلال العهـر والعينـة الكليـة للاختبـارات الفرعية، وقد أظهرت النتائج أن الدرجة الكلية للبطارية القياسية ومقاييس (PASS) مرتفعة في الثبات الداخلي فمتوسط معدل الثبات الكلي يكون لأقل من 90 . . وأعلى من و 9 . ..

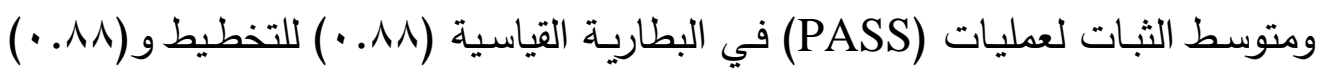
للانتباه و (r9 . ·) للتآني و( 9 9. ) للتتابع، كما أن معاملات الثبات للبطاريـة الأساسية أيضـا

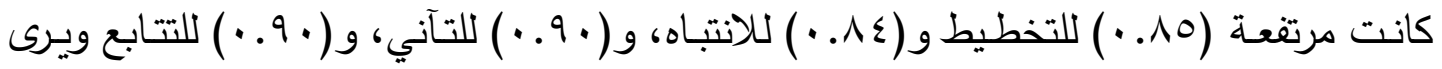
براكن "Bracken" أن الثبات المرتفع للاختبارات الفرعية يتراوح من(0 . . - . . . ) بمتوسط

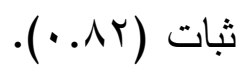

تم حساب معامل ثبات الاختبار في الدراسة الحالية عن طريق إعادة تطبيق الاختبار بفاصل زمني مدتـه ثلاثون يومًا بالطريقة التقليديـة أي بإتبـاع تعليمات القيـاس المدونـة بدليل الاختبار ، على عينة الدراسـة الاستطلاعية وقوامها (ro) طفلاً وطفلـة من الأطفال المقيدين بالمستوى الثاني برياض الأطفال، وبعد إيجاد معامل الارتباط بين التطبيقين كانت قيمة معامل الارتبـاط مرتفعـة ودالة إحصـائيا عند مستوى دلالـة ( ( ...)، كما يتضـح من نتائج الجدول

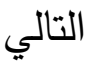




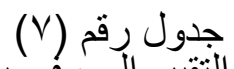

معامل ثبات منظومة التقييم المعرفي بطريقة إعادة التطبيق

\begin{tabular}{|c|c|c|}
\hline معامل الثبات بطريقة إعادة التطبيق & الاختبار ات الفرعية & العمليات العقلية \\
\hline. .1 & | مضاهاة الأرقام & \multirow{4}{*}{ التخطيط } \\
\hline. .9 & التخطيط لحل الرموز & \\
\hline. .9 & التخطيط (التوصيل) & \\
\hline. .9 & مجموع & \\
\hline. .9 & |المصفوفات غير اللفظية & \multirow{4}{*}{ ل ل آتآني } \\
\hline. .1 & |العلاقات اللفظية المكانية & \\
\hline. .9 & |ذاكرة الأشكال & \\
\hline. .9 & مجموع & \\
\hline. .9 & |أساس ثبات المدرك & \multirow{4}{*}{ ل الاتتباه } \\
\hline. .9 & البحث عن الأعداد & \\
\hline. .1 & أساس تغيير المدرك & \\
\hline. .1 & مجموع & \\
\hline. .1 & سلاسل الكلمات & \multirow{4}{*}{ التتابع } \\
\hline..$V$ & اختبار إعادة الجمل & \\
\hline. .9 & معدل تكرار الكلام & \\
\hline. .1 & مجموع & \\
\hline. .9 & & الدرجة الكلية \\
\hline
\end{tabular}

تم حسـاب الصـدق باسـخدام صـدق المحك في منظومـة التقييم المعرفي من خـلال

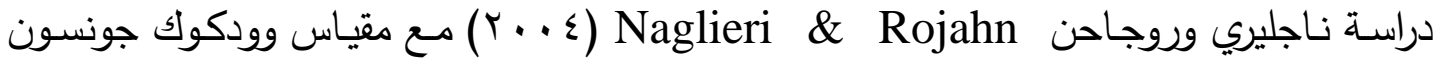

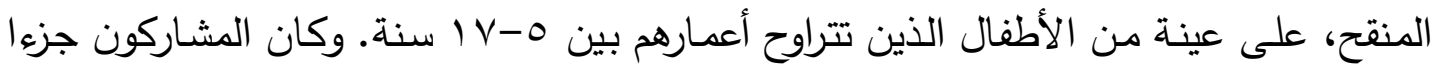

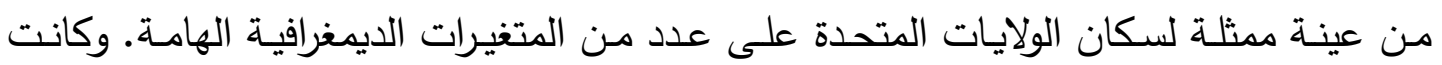
نتائج ارتباط بيرسون بين الدرجة الكلية لمقيـاس الكاس ( (V. • )، ولدرجات البطاريـة الأساسية ( • • • ( )، وبذلك قد تم الحكم على صدق منظومة الكاس من خلاله. تم حساب صدق الاختبار في الدراسـة الحالية باستخدام طريقة صدق المحك الخارجي، حيث تم حسـاب معامل الارتباط بين درجات عينـة الدراسـة الاستطلاعية وكان عددها (ro) طفـل وطفلـة مـن الأطفـال المقيـدين بالمسـتوى الثاني بريـاض الأطفـال على منظومـة التقيـيم 


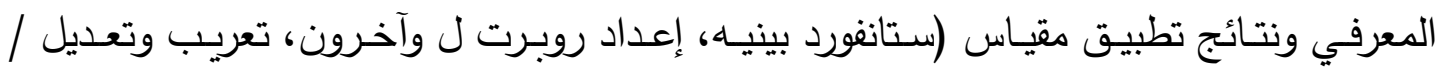

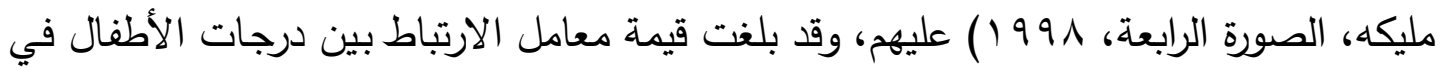

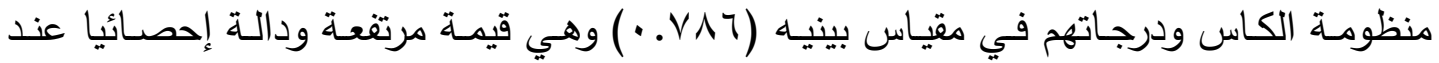

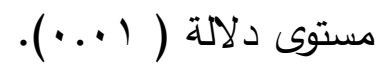
نتائج الدراسة ومناقشتها

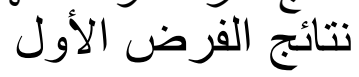

وينص الفرض الأول على " توجد فروق ذات دلالــة احصـائية بين متوسط درجـات

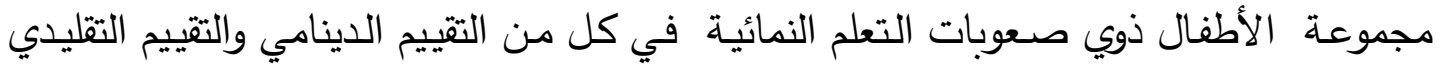

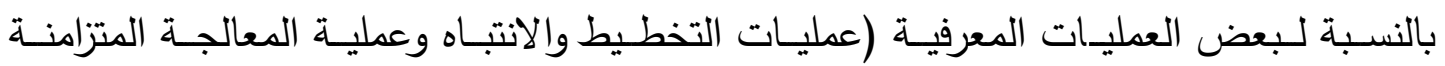

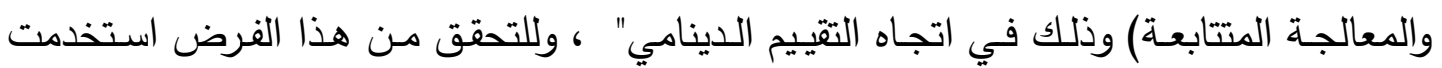

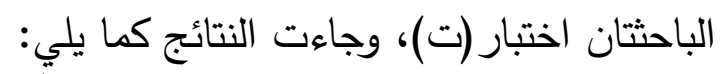

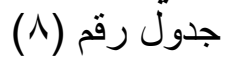

يبين اختبار "ت" لتحديد مستوى الفروق واتجاهها بين متوسط درجات مجموعة الأطفال ذوي

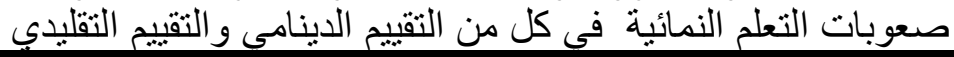

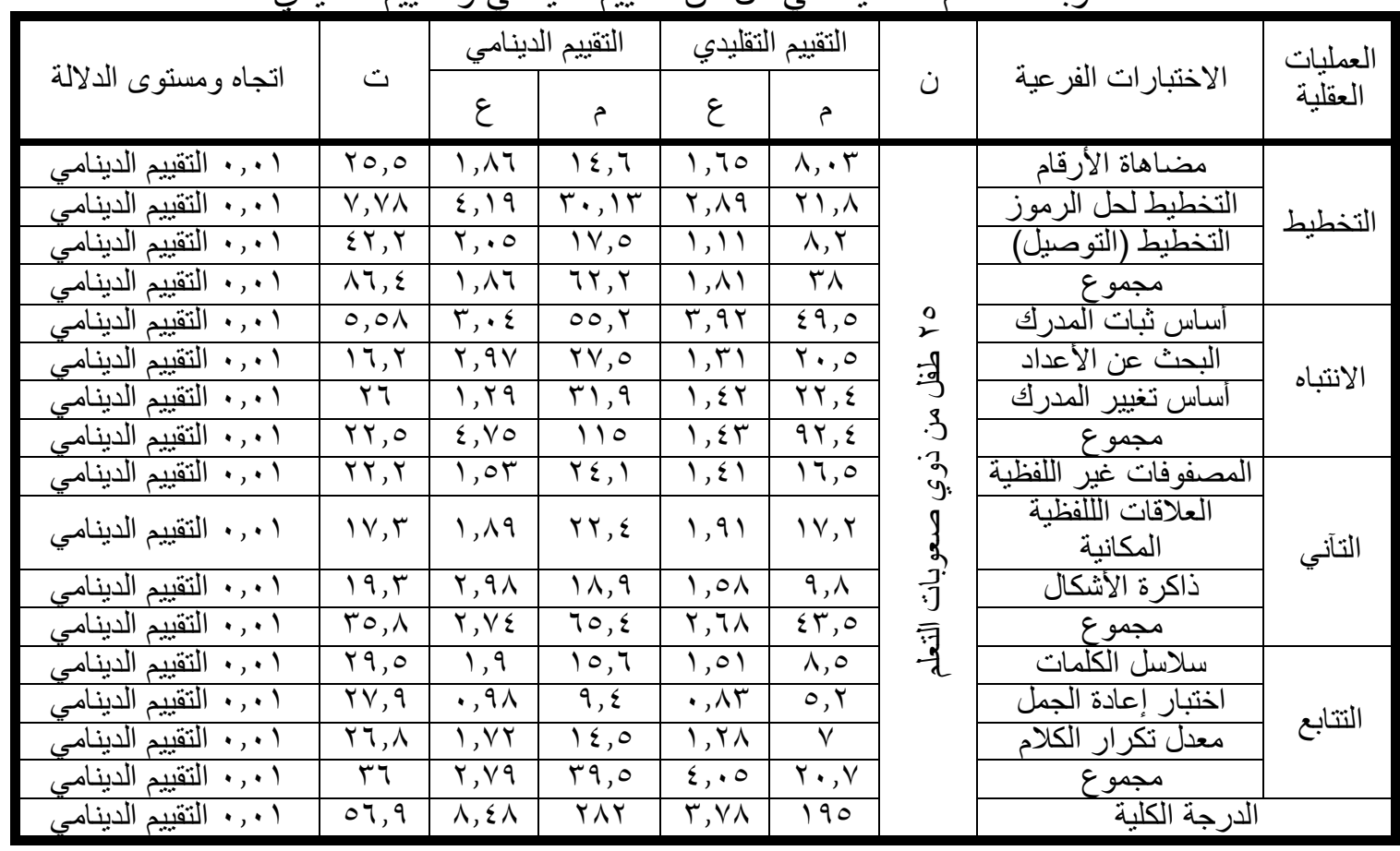

يتضـح مـن جدول (^) أن قيمـة " ت " الدحسوبة أكبر مـن القيمـة الجدوليـة البالغـة

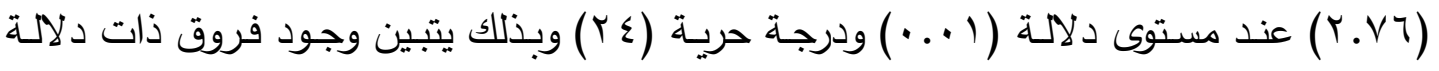
إحصائية بين متوسطي درجات الأطفال ذوي صعوبات التعلم النمائيـة على منظومـة التقييم 
المعرفي في الأداء بالمنحى التقليدي مقارنـة بالأداء بالمنحى الدينامي في الدرجة الكلية وفي الدي

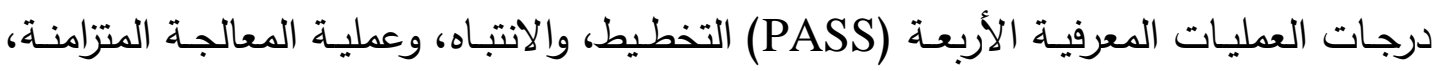

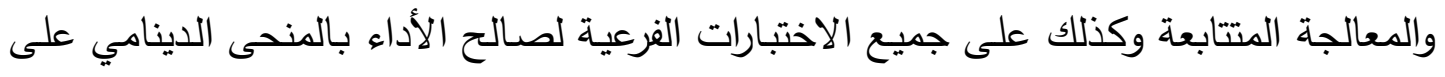

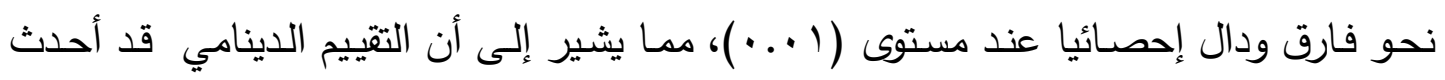

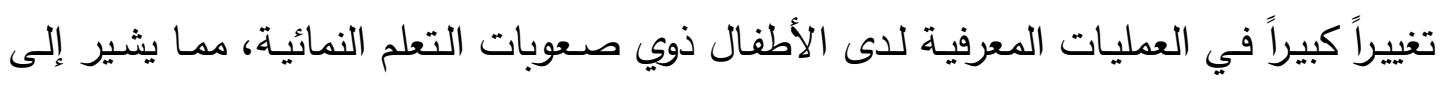

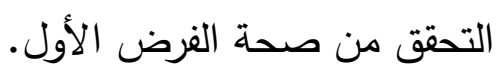

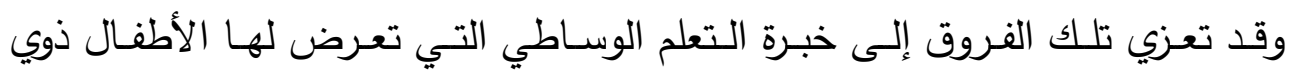
صعوبات التعلم النمائية أثناء عملية التقييم الدينامي، والتي تقوم على التفاعل النشط بين التئي الطفل

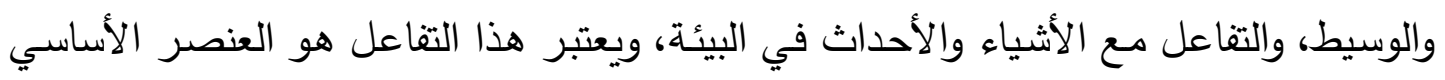

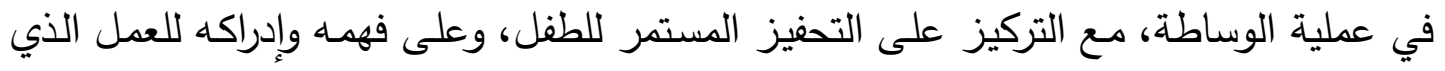

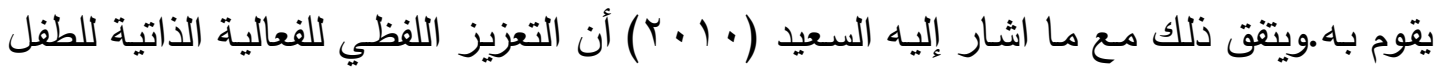

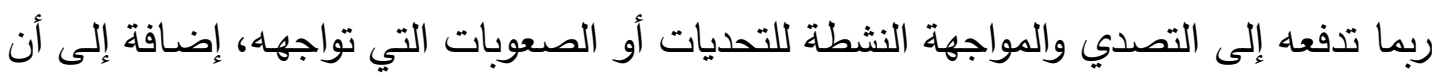

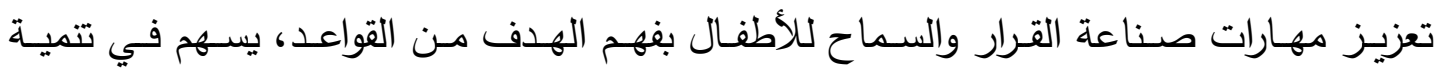

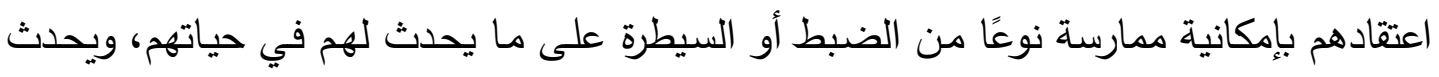

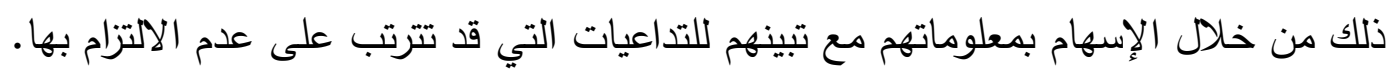

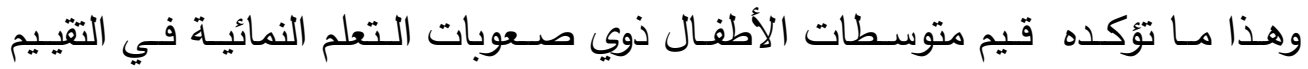

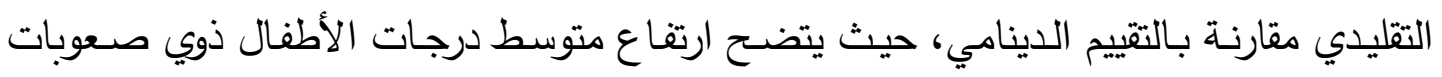

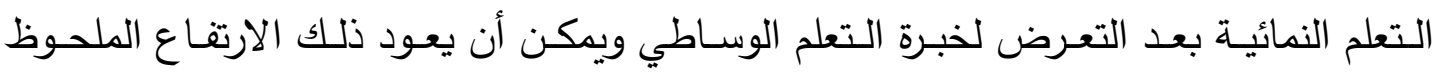

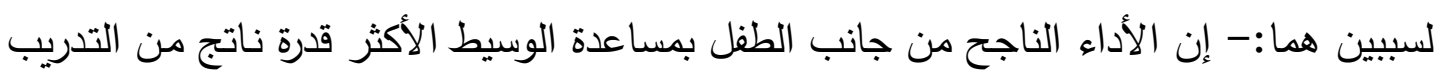

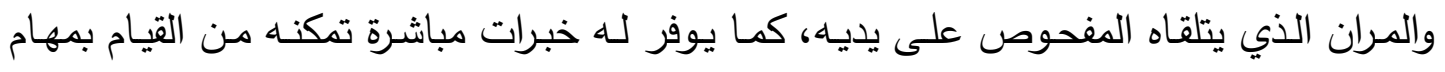

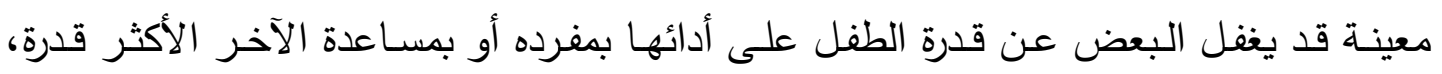

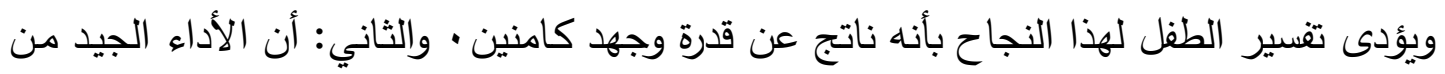

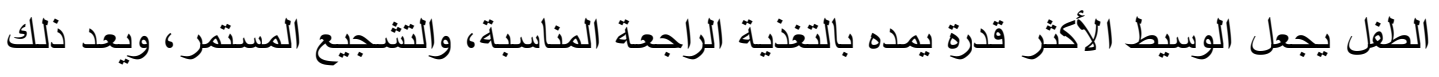

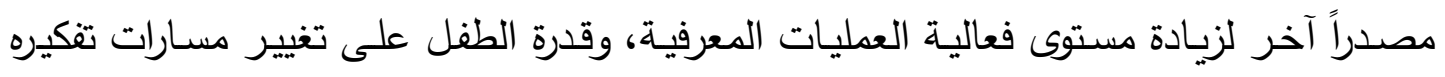
بطرق مختلفة لإعمال عقله وتتمية قدراته. 
Kaniel \& Reichenbergوقد اتقتت الدراسة الحالية مع دراسة كانيل وريكينبيرج

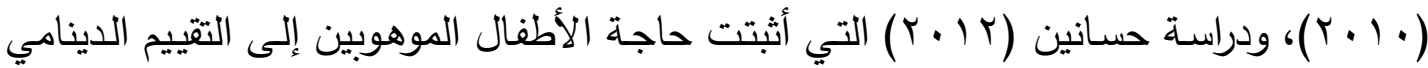
كأداة من الأدوات التي تمكنهم من التقدم وتحقيق إمكانياتهم، بهـا يساعد على تقليل الفجوة الكبيرة الكائنة بين قدراتهم العقلية وإنجازاتهم الأكاديمية وسدها من خلال فعالية التعلم الوساطي، لذا ينبغي أن يستخدم التعلم الوساطي لإتاحة الفرصـة للأطفال الموهوبين لإكتساب القدرة على

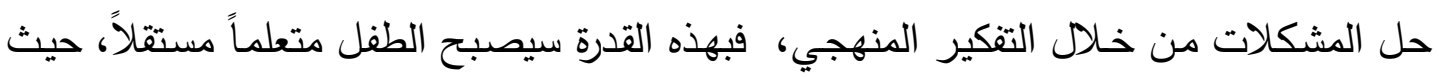
يستخدم مهاراته في التنكير في مواقف الحياة الحقيقية.

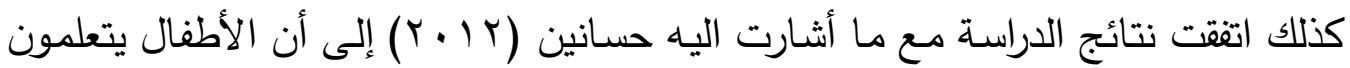
عندما يكون المعلم موجهًا نحو ما يسميه فيجوتسكى منطقتهم / مجالهم من النمو وتشتمل هذه المنطقة على المهام التى تكون فى مدى من الصعوبة يقع بين مـا يستطيع الطفل أن يفعله بشكل مستقل وما يستطيع أن يفعله بالمساعدة، والبعض يسمى هذا المدى Goldi Locks لأنه ليس بالسهل جداً ولا بالصعب جداً إنه على الأغلب متوسط / مضبوط - فإذا كانت قدرات الطفل لا تتسجم مع المستوى التعليمى فإنها لا يمكن أن تظهر .

$$
\text { نتائج الفرض الثاني }
$$

ينص الفرض الثاني على " توجد فروق ذات دلالة احصـائية بين متوسط درجات التقييم

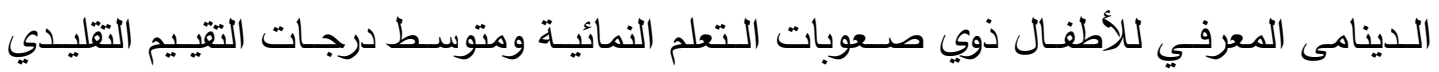
للأطفال العـاديين وذلك على مقياس التقييم الدينامى للعمليات المعرفيـة (عمليـات التخطيط والانتبـاه وعمليـة المعالجـة المتزامنــة والمعالجـة المتتابعـة) في اتجـاه درجـات التقييم الدينامي للأطفال ذوي صعوبات التعلم"، وللتحقق من صحة هذا الفرض استخدمت الباحثتان اختبار "ت" وجاءت النتائج كما يلي:

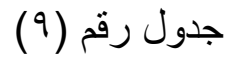

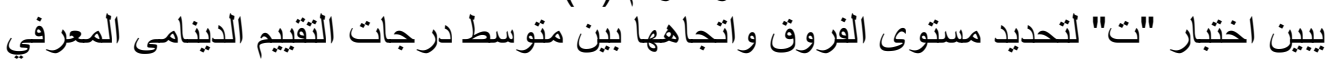

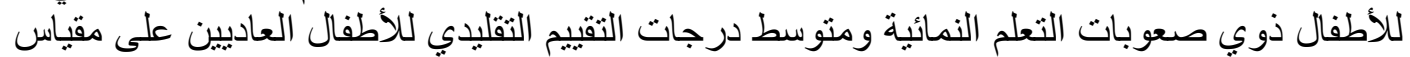

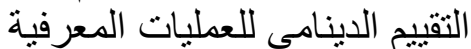

مستوى و اتجاه الدلالة قيمة ت الأطفال العاديين الأطفال ذوي 


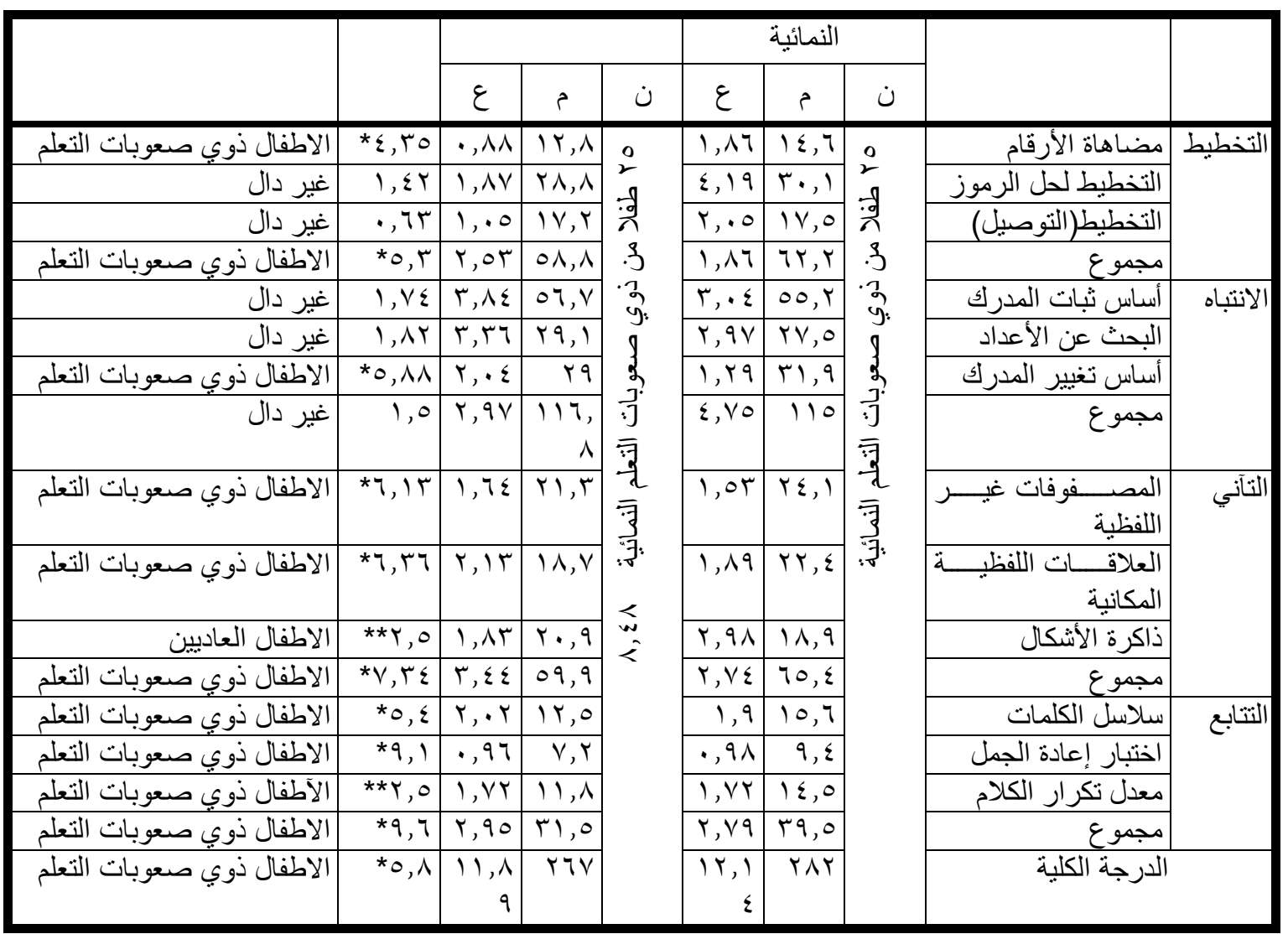

قيمة " ت " الجدولية = (Y.VT)

*دال عند مستوى ا... *** دال عند مستوى 0...

تشير نتائج جدول (9) إلى وجود فروق ذات دلالـة احصـائية وجوهريـة بين نتائج التقييم الدينامي المعرفي للأطفال ذوي صسوبات التعلم ونتائج التقييم التقليدى للأطفال العاديين في اتجاه الأطفال ذوس صعوبات التعلم النمائية وذلك بالنسبة لمعظم الأبعاد والاختبارات الفرعيـة، فقد بلغت مستويات الدلالـة للفروق عند مستوى ا ... أبعاد التخطيط والتأني والتتابع والدرجة الكلية، بينما لم تشر النتائج الى وجود فروق دالة احصائيا بالنسبة للانتباه. وقد جاءت نتائج الدراسة معبرة عن تحقق الفرض العلمي للدراسـة ومخالفة لمعظم الدراسـات التى قارنت بين الاطفال ذوي صسوبات التعلم النمائية والأطفال العاديين في مرحلة الروضـة، وهو مـا يرجع إلى فاعليـة استخدام التقييم الدينامي المعرفي بكفاءة أحدثت تفوقاً للأطفال ذوي صـوبات التعلم النمائية مـن حيث الأداء على الأطفال العـاديين في ضـوء عمليات التدريب والتخطيط والانتباه والتأني والمتابعة التي تم التدريب عليها أثناء عملية القياس فضـاً عن دور التدخل الوساطي الفاعل والمؤثر للمعلمة الذي جعل من موقف الاختبار موقفاً تعليمياً تفاعلياً 


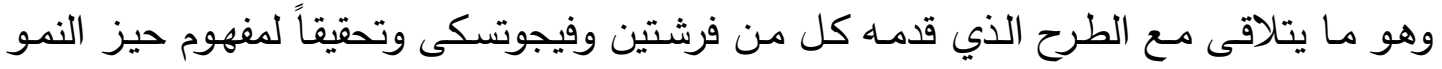

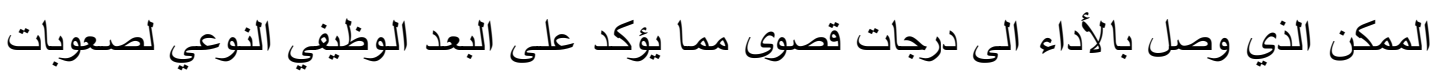
التعلم النمائية.

ويمكن تفسير هذه النتيجة بأن الطفل لكي نستطيع تتمية قدراته العقلية وعملياته المعرفية

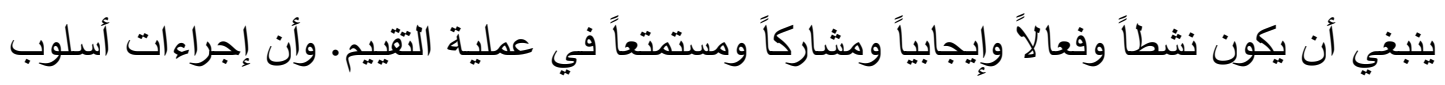

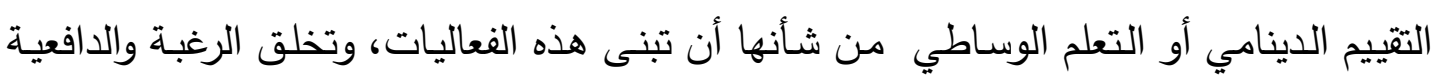

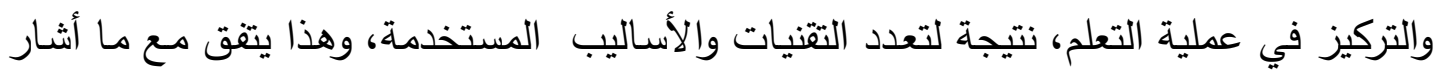

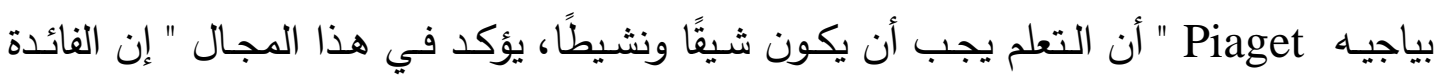

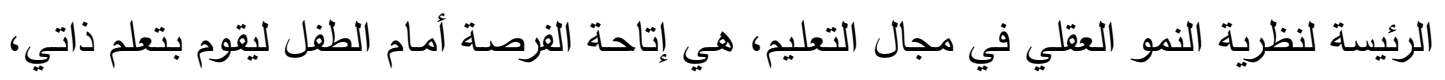

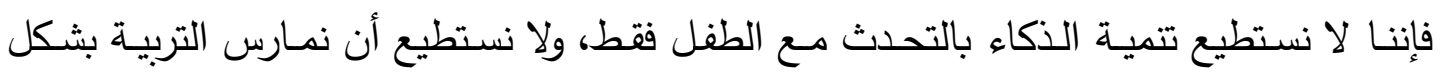

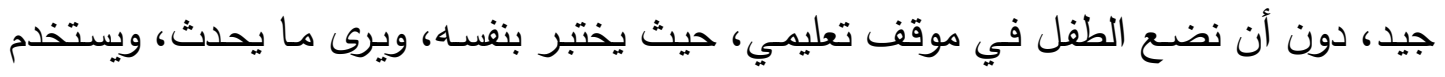

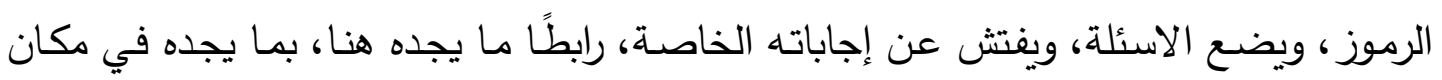

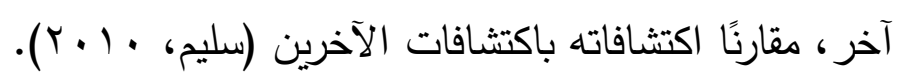

توصيات البحث

1- التوسع في نطاق استخدام التقييم الدينامي المعرفي بدلا من التقييم التقليدي في جميع

المراحل التعليمية.

ץ- تضـمين الاختبـارات والمقـاييس النفسية والتربويـة على مفهوم التقيـيم الدينامي كبديل

للتقييم التقليدي.

r- تطبيق التقييم الدينامي على فئات بحثية مختلفة ومتعددة للتحقق من فاعليته ونتائجه.

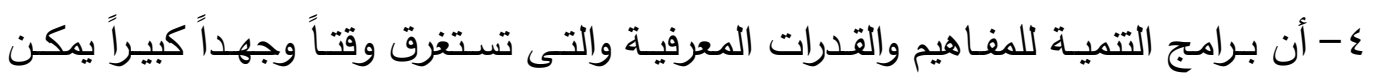
استبدالها بالتقييم الدينامي المعرفي والذي يوفر الوقت والجهد. 


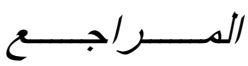

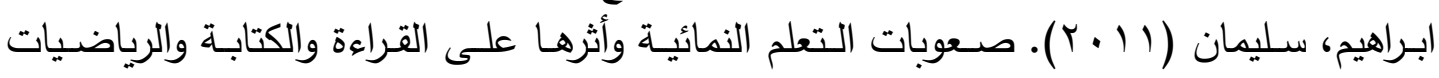

$$
\text { والعلوم، القاهرة: مطابع الدار الهندسية. }
$$

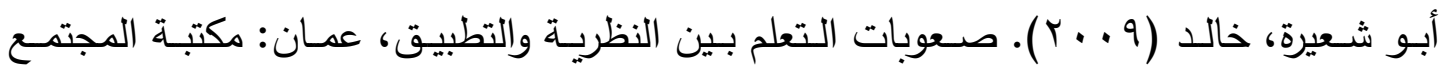

$$
\text { العربي للنشر والتوزيع. }
$$

أحرشا، الغالي؛ والزاهر ، أحمد ( . . . ب). التمدرس واكتساب المعارف عند الطفل. مجلة العلوم

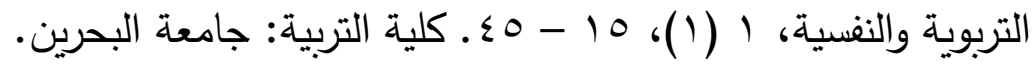

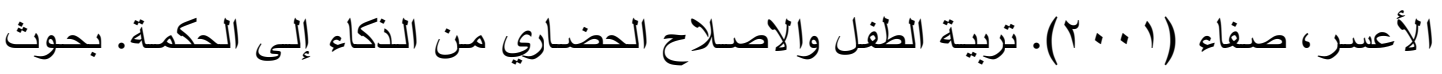

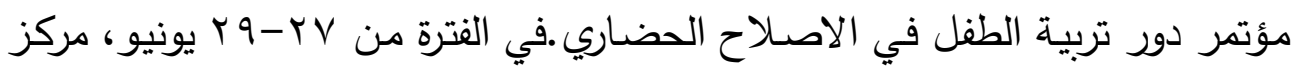

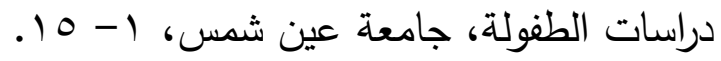

الأعسر ، صفاء ( • ( • ). علم النفس الإيجابي ودراسـة الموهبة،اكتشاف الموهبـة ورعايتها من منظور نموذج رينزولي الإثرائي. عمان:الملتقى الخليجي الأول لرعاية الموهوبين.

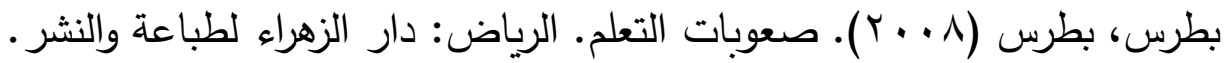
بلجون، كوثز (· ( • (Y). تدريس مهارات التفكير • المملكة العربية السعودية: جامعة أم القرى.

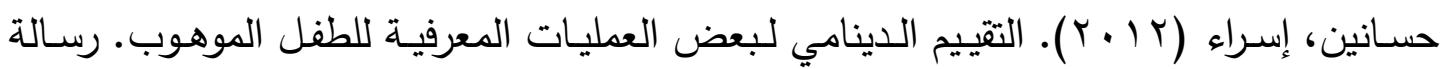
دكتوراه، كلية رياض الأطفال، جامعة القاهرة.

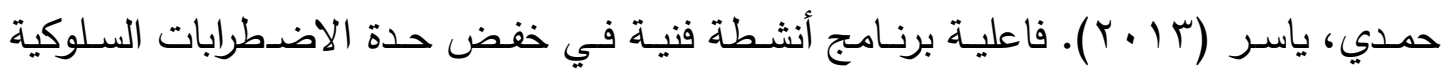

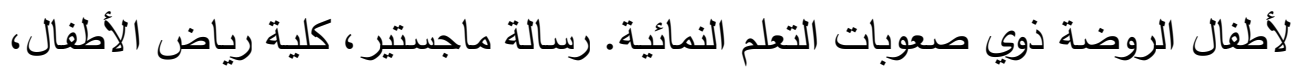
جامعة القاهرة.

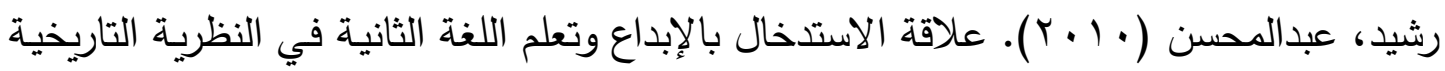
الثقافية الاجتماعية لفيجوتسكي. الرياض: اهن: جامعة الملك سعود. الزيـات، فتحي (9 . . r). الأسـس المعرفيـة للتكوين العقلي وتجهيز المعلومـات. القـاهرة: دار النشر للجامعات. سليم، مريم (· ( • ). قياس وتقييم النمو العقلي والمعرفي بريـاض الاطفـال. لبنـان: الجامعـة اللبنانية.

الشيخ، حنان (ع . . ب). دراسـة في المقارنـة بين التقييم الدينامي والتقليدي باستخدام نظريـة باس

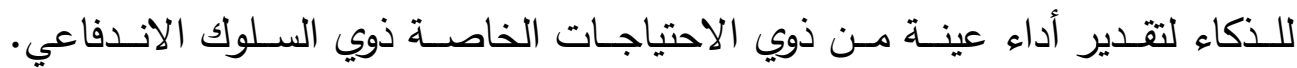

$$
\text { القاهرة: ايتراك للنشر والتوزيع. }
$$

طه، محمد (T . . Y). الذكاء الإنساني اتجاهات معاصرة وقضايا نقدية.الكويت:عام المعرفة. 
عازم، أحمد؛ والباسل، إعتدال (T . . Y). تجربـة التعلم الوسـاطي في الطفولـة المبكرة. مجلـة

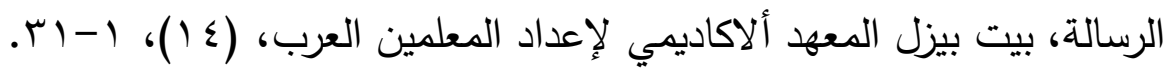

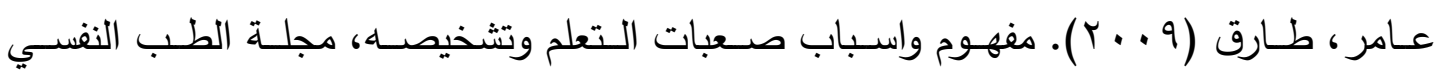
الإسـلامي (النفس المطئنـة)، تصدرها الجمعيـة العالميـة الإسـلامية للصحة النفسية

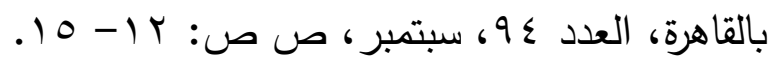

عباس، فيصل (.... (Y).الاختبارات النفسية تقنياتها وإجراءاتها، بيروت: دار الفكر العربي.

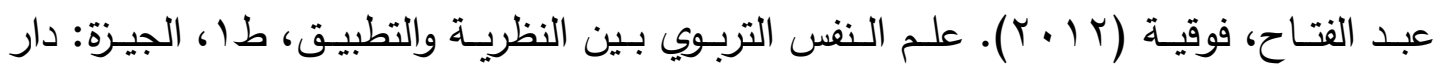
النهضة.

علام، صلاح الدين ( . . . r ). القياس والتقويم التربوي والنفسي أساسياته وتطبيقاته وتوجهاته

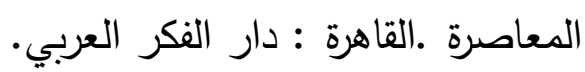

علوان، فاديـة (Y99 1 ). ارتقاء المعالجـة الآنيـة والمعالجـة المتعاقبـة عند الأطفال في المرحلـة

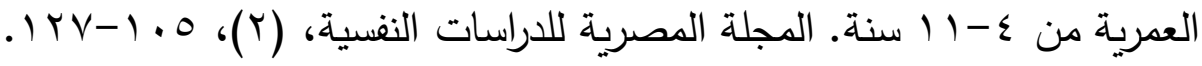

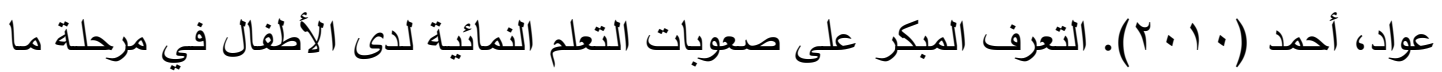
قبل المدرسة. موقع منار للتربية الخاصة.

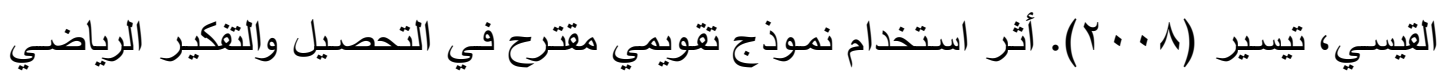

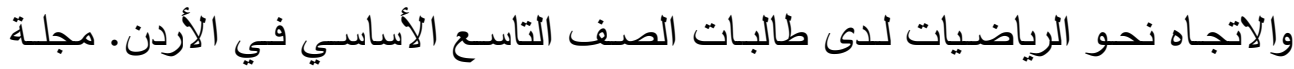

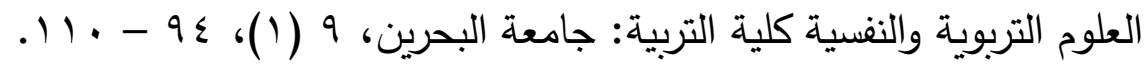

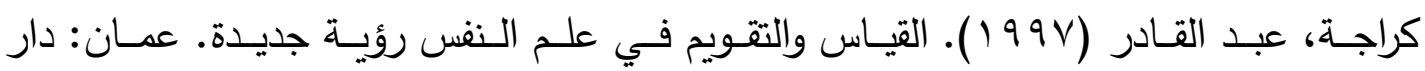

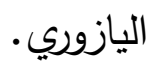

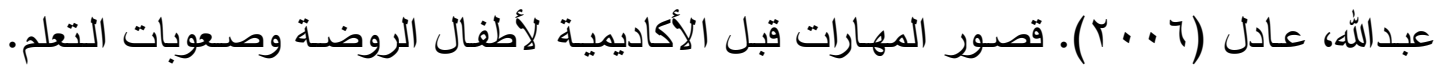

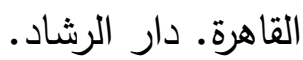

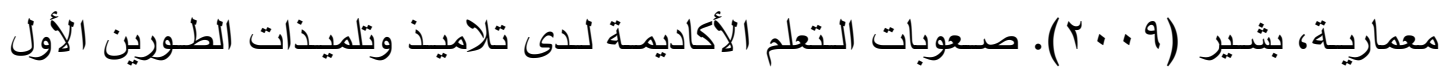
والثاني من التعليم الابتدائي، المنصورة: الدكتبة العصرية للنشر والتوزيع.

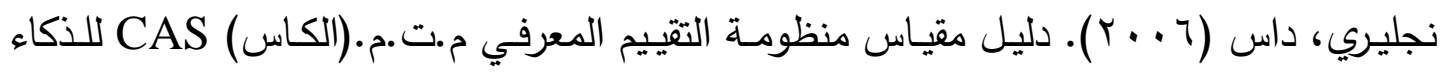
(ترجمه أعده وقننه على البية المصرية والعربية: أيمن الديب). القاهرة: مكتبة الأنجلو. 
Baek,S.\& Kim, K. (2011). The Effect of Dynamic Assessment Based Instruction on Children's Learning. International Journal of Language Studies (IJLS), 5(1), 125-140.

Chessman, A. (2006). Identification of Students from Culturally Diverse Backgrounds: Coolabah Dynamic Assessment Model (CDAM). State of New South Wales:NSW Department of Education and Training.

Clabaugh, G. (2010). The Educational Theory of Lev Vygotsky:a multidimensional analysis.USA.:New Foundation.

González, L., Palencia, P.,Umaña, A.,Galindo\& Villafrade, M.(2008).medical learning experience and concept maps: a pedagogical tool for achieving meaningful learning in medical physiology students. Advan in Physiol Edu ,32, 312-316 .

Gutiérrez-Clellen,v. \& Peña,E.(2001). Dynamic Assessment of Diverse Children. Language, Speech, and Hearing Services in Schools, $32(4), 212-224$.

Hasson, N. \& Botting, N.(2010). Dynamic assessment of children with language impairments: A pilot study. Child Language Teaching and Therapy.26 (3) , 249-272

Hasson, N. \& Joffe, V.(2007). The case for Dynamic Assessment in speech and language therapy. London, UK:Department of Language and Communication Science. 
د/ نهى محمود الزيات \& د/ رحاب السبد الصاوي التقييم الدينامى المعرفي لمؤشرات صعوبات التعلم النمائية لإطفال الروضة

Holzman, L.(2002). Vygostsky's Zone of Proximal Development: The Human Activity Zone. Chicago: Presentation to the Annual Meeting of the American.

Kalyuga, S. \& Sweller, J. (2005). Rapid dynamic assessment of expertise to improve the efficiency of adaptive e-learning. Journal Educational Technology Research and Development. 3 (53), 8393.

Kaniel, S. \& Reichenberg , R. (2010). Dynamic Assessment and Cognitive Program for Disadvantaged Gifted Children. Israel: Bar Ilan University, School of Education.

Kapantzoglou,M.,Restrepo,M.\&Thompson,M.(2012).Dynamic

Assessment of Word Learning Skills: Identifying Language Impairment in Bilingual Children. Language, Speech, and Hearing Services in Schools, 43(1) ,81-96.

Lantolf, J. \& Thorne, S. (2006). Sociocultural Theory and the Genesis of Second Language Development. Oxford: Oxford University PressZ.

Lidz, S. (1991). Practitioner's Guide to Dynamic Assessment (Paperback) .New York:The Guilford Press .

Lidz, S.\& Elliott , J. (2000). Dynamic Assessment: prevailing Models and Applications. New York: Elsevier Science Inc.

Marsh, G.\& Ketterer, J. (2010). Situating the Zone of Proximal Development. Georgia: University of West Georgia. 
Naglieri , J. (2008). Cognitive Assessment System.USA:Education and culture DG lifelong learning Programme.

Poehner, M., \& Lantolf, J. (2005). Dynamic assessment in the language classroom. Language Teaching Research. 9, 233-265.

Rajeev,1. (2010). Zone of Proximal Development. United States: Buzzle.

Sternberg, R. \& Davidson, J. E.(2005). Conceptions of giftedness, Second Edition. United State of America: Cambridge University press.

Sternberg, R. \& Grigorenko,E. (2002). Dynamic testing: the nature and measurement of learning potential. United state of America: Library of Congress .

Thomas, J. (2008). Towards dynamic diagnostic assessment. Northern Kentucky University: Kentucky Center for KCM Mathematics.

Toscano, L. (2009). Vygotsky's Zone of Proximal Development. University of California: Riverside Extension Foundations 091EDFF01.

Yildirim, O. (2008). Vygotsky's Sociocultural Theory and Dynamic assessment In Language Learning. Anadolu University Journal of Social Sciences Cilt. 8 (1), 301-308. 